\title{
BORÇLLARIN SUKUTU
}

\author{
Prof. Dr. Sakir BERKI
}

\section{I - BORÇLARIN SUKUTUNUN MANASI}

Mevcut bir borcun alacakl tarafindan artk mutalebe edilemez hale gelmesine borcun sukutu denir. Demek ki, sukutda borcun mutlaka ortadan kalkmasina lüzum olmayıp kanunen mutalebe edilebilmek kabilliyetini zâyi etmesi keyfiyeti mühimdir. Bunun içindir ki tarifi bis şekilde yapmay daha münasip ve hukuk tekniğine daha uygun bulduk. Her ne kadar sakst olan borç umumiyetle mevcudiyetini de gaip eder ise de bu, bir kaidedir. Binnetice istisnasi mevcuttur. Messlâ mü|rurzaman sukut sebebidir; fakat borcu bertaraf etmez mutalebe edilebilmek vaisfını zevale uğratır ${ }^{1}$. Şu halde tarifi yukardaki gibji yapmış olmasaydik şumullü olmazdı, ve mürur zaman sukut sebeblari haricinde kalırdı.

\section{II - BORCLARIN SUKUTUNA DAIR UMUMI KAIDELER}

Bu bahiste her borcun sukutunda, her sukut sebebinide müş̧terek bazı kaidelerden bahsolunacaktır : Bu müsterek k'aideler sukutun neticelerine ait olup ikidir.

A : Borç sakıt olunca ferîleri de sakıt olur.

B : Borcun sukut edebilmesi için tamaminın sakıt olması lâzım: ideğildir. Yani sukut kısmi de olur.

A - Borç sâkut olunca ferîleri de sakut olur:

Borcu iskat edien esbap assl borca merbut, mevcudiyetleri asıl borcun mevcudiyeti kaim bütün hak ve mükellefiyetler de sakıt olur.

1) Mürurzamana uğramış borç tabiî borç olarak bâkidir. Öyle olmasa idi müruru zamana uğramıs bir borcun tecdidi mümkün olmayacağı gibi, ifası da muteber olmazdı. Mürurzamana uğramıs borcun tecdidi için "tecdit" bahsine bakınız. 
Kefalet rehin ${ }^{2}$ zamanı rücu, cezaî şart gibi ${ }^{3}$. Para borçlannda fâiz: dahi müteferrî blir borçtur. Binnetice resülmâl ifa veya sair sebeblerle: sakıt olsa, fâiz dlahi borçludan istentemez. Maamafih, kanun, fâiz borcunun sukutu hakkında bazı ayn klaideler kaymuştur : Evvelce işlemiş. olan fâizler dahihi asıl borçla birlikte sakıt olur. Lâkin hilâfe kasdedilmis; ise hüküm aksinedir. 113/2. Vaktiyle işlemiş olan fâizler Mahkeme: veya icrada takip edilmeye başlanmış ise mukavelede hilâfı șart edilmiş olmasa bile artık bunlar asıl borcun sukutu ile düşmızler. (Icraî. takibat veyła dava dü̈łme(z). Böyle fâiz borçlannın sukutu için sukut: sebeblarinden birinin bunlar hakkinda müstakillen husulü icap eder.

88 nci maddede "alacaklı resülmâl için makbuz vermiş ise fâizleri de tahsil etmiş sayılır" denmektedir. Bu hüküm fâizlerin sakıt olduğu manasında tefsir olunmamalıdır. Murat, böyle bir halde borçlunun eda karinesinden müstefit olacağından ibareitir. Fâizleri tahsil etmemiş olmasına rağmen resülmâl icin makbuz veren alacakh fâizleri almadığını ispat ederse karineyi çürütür ve fâizleri de bilâhare tahsil ede-. bilir ${ }^{4}$.

\section{$B$ - Sukutưn tam olmasis lâzam değildir.}

Borcun sakıt olması için sukut sebəbinin sukut edsze's olın borcun tamamına sâri clması şart değildir. Şu halde kısmî sukut da muteberdir. A, B ye 100 lira borçlu olsa, 20 lira ibra etse, borç bu miktar dahilinde sakıt ou'r., 80 lira bâkidir. Yine meselâ A, B ye 100 ton buğ. day teslimine borçlu olsa, 80 tonunu teslimiden sonra, 20 ton mevzude imkânsızluk sebebiyle sakıt olaḱlilir. Yine bilfarz, A nın B den 100 lirz alacağı olsa, B nin de A dan 60 lira lalacăğ bulunsa 100 liralık borç takasla kismen sakıt olup $\mathbf{4 0}$ liraya tenezzül edebilir

2) Rehin her sukut halinde sakıt olmaz. Zira mürur zaman bahsinde görüleceği üzere asıl borç sakıt olsa bile, rehin hukuku devam eder. 138 ncí madde : "Alacağın bir menkul rehni íle temin edilmiş bulunması bu alacak hakkında mürur zaman cereyanına mâni olmaz. Fakat alacaklı rehinden istifayı hak etme selâhiyetini muhafaza eder" demekle fer'i hak olan rehnin sakıt olmayacağı keyfiyetini teyid ediyor.

Cezaî șart talep edildikten sonra borç sakıt olsa bile talep edilen cezaí şart sakıt olmamak lâzımdır.

4) Resülmâl için makbuz almış olan borçlunun fâizi ödemediğini ikrar etmesi, veya işlemiş fâizlerin makbuz verildikten sonra kısmen edası gibi ahval dahi karinenin çürütülmesi için kâfi delillerdir. Bütün bu hususatın ispatr alacakliya düşer. 


\section{III - BORCLARIN SUKUT SEBEBLERININ TASNIFI}

Borcun sukut sebebleri umumî olarak ikiye ayjulır :

1 - Alacaklıy tatmin eden sukut sebebleri.

2 - Alacaklıy tatmin etmeyen sukut sebebleri.

Alacaklıyı tatmin édien sukut sebeblerinde borç ala'caklının akdî münasebetten menfaattar olması ile, diğerinde alacaklı akitden müstefit olmaksizin sakit olur.

Alacaklıy tatmin eden sukut sebebleri, Ifa, Takas, Tecdit. Alacaklı ve borçlu sıfatlarmın birleşmesidir.

Allacakliyı tatmin etmeyen sukut sebebleri de : İbra, blorç mevzuunun sonra'dan imkânsız hale gelmesi, ve mürur zamandır.

Ehemmiyetlerine binaen her sukut sebebinin ayn ayn incelenmesi zaruri olduğu gibi, esasen sadedi teşkil eder.

1 - Alacakliyı taimin eden sukut sebepleri :

A) Ifa.

B) Takas (Campensation)

C) Tecdit

D) Alaicaklı ve borçlu sufatlannın birleşmesi.

A) Iffa.

Ifa borçlann normal, ve mukavele gayesine uygun sukut sebebidir. Ifa halinde borç kanunen tamamen sakıt olur. Zira kaideten ifa tam olmak lâzımdır. Mukavelede sarahat varsa veya olmayıp da alacaklı sonradan ifa sırasında kısmî edaya sarih veya zımnî sekilde razı olmus ise, kısmi ifa dahi sukut sebebi olur; bu halde borç ifa nisbetinde sakit olur. A, B den 100 lira al'acaklh olsa, prensip itibariyle muacceliyet zamanında 100 liranın hepsini eda ile mükelleftir. Fakat akitle veya filen kısmî eda alacaklı tarafindan kabul edilmiş ise borç o veçhile kısmen sakit olur.

Ifadan maksat alacaklının tatmin edilmesini teminden ibaret olduğuna göre, borçlunun mutlaka alacakliya akitdeki mevzuu teklif etmesi de şart değildir. Borçlu ödemekle mükellef olduğu para yerine alacakhya bir başka şey teklif edebilir. Veya bu keyfiyet mukavelede 
daha evvel derpiş edilmiş olabilir. Edanın bu tąrzda vukuuna "ifa yerine geçen eda" denir.

Bir iki misal zâit olmaz : A, B den 50 lira alacaklıdır. B muacceliyet zamanında veya daha evivel alacakliya 50 lira yerine geçmek üzere bir dolma kalemi vereceğini beyan etse, ifa yerine geçen eda mevzuubahis olur. A, B ye iki at teslimini borçlu olsa bir at yerine alacaklıy bir bisikletle tatmin etmeyi düşünce ve alacaklı da razi olsa bu borç hem ifa, hem ifa yerine geçen eda birlikte məvicultur. Birinci atin teslimi ifa, ikincisi yerine bisiklet verilmesi de ifa yarine geçen edadır.

Kaydedilecek cihet ikidir:

1) İfa yerine geçen eda mahiyet' itibariyle ifa ad'dedilaceğinden, ifanın tâbi olduğu kayıtlarla mukayyettir. Vâdle, mưacceliyet şartlan, ifa mahalli hep esas borcu doğuran mukaveleye göre tâyin edilir.

2) Ifa yarine geçen eda illk bakışta tecdilde benzer ise de, tecdit bahisinde görüleceği üzere, ondan farkhdır !: Ifa yerine gieçen èdada yeni bir borç doğmaz, sâbık borcun tarzı ifası değişir.

B) Takas (Compensation).

a) Tarifi

b) Mahiyeti

c) Sartlan

d) Mütefarrik hükümler

a) Takas'n tarifi :

Karşlukh alacakh ve Worçlu olan şahısların müteaddit ve mütekabil eda külfetinden kurtulmak ülzere yekdiğeri nezdindeki alacak ve borçlannı eda edilmiş gibi kabul ve farz etmeleridir. Mahsup neticesinde eda edilmiş farz ve kabul edilen alacak ve borç miktarlan sakit olur. A, B den 100 lira, B A dan 90 lira alacakli olsa, takas edilince 90 ar lijualik borç sakıt olur. 10 lira A lehine devam eder.

Görülüyor ki, takasida her iki borcun mutlaka tamamen sakıt olması kaide değildir. Fakat bir tarafin borcu behemehal sakıt olur. Karşlıklı alacaklar miktar itibariyle müsavi ise takas her iki borcu da iskat eder. 
Alelâde mahsup ile takas arasındaki fark şöyle izah olunur : Alel'âde mahsupta alacaklann yekdiğerinden tenzili için takas şartlan aranmaz. Binnetice muaccell olmayan bir biarç ile muaccel borç mahsup olunabilir. Halbuki, takasın sartları bahsinde görüleceği gibi, böyle alacaklarm tak'ası kabil değildir. Hattâ mürur zamana uğramış bir borç ile uğramamış bir borç bu sonuncusu henüz muaccel olmamışbulunsa bile mahsup eldilebilir. A, B deki alacağı 1000 lilradian vaktiyle B ye tediyeye lâzım gelipte mürur zamanla sakıt olmuş olan 500 iiranın mahsubuna razi olabilir. Bu, bir ibra değildir, mürur zamanla tabiî bir borç haline inkilâp etmiş olan bir borcun ifası yerine geçen eda hükmündedir.

b) Takasın mahiyeti ve faideleri :

Tarifinden de anlaşılacağı üzere takas, müteaddit ve faydasiz mütekabil elda külfet ve masraflarından azâd eder. Bu bakımdan pek faydalı bìr müessese olup bilhassa ticarî hayatda âdeta ifa hükmündedir.

c) Takas'in șartlain :

İki alacağğın takasında şu şartlar ve esaslar câridir :

$\left.1^{\circ}\right)$ Her iki alacak da muaccel lolmalidir.

$2^{\circ}$ ) Her iki alacak da aynı cinsten olmalidar.

$3^{\circ}$ ) Takas edilecel alacaklann miktar itibariyle müsavi olmasına hacet yoktur.

$4^{\circ}$ ) Takas yalnı (para alacaklarına münhasır değildir.

$5^{\circ}$ ) Takas, alacaklardan biri münazaalı ol'sa dahi dermeyan olunabilir.

Takasła alâkalı bu şantlar ve kaideler tüzerinde durduktan son'ra, müteferrik hüikümleri muhitevi bulunan 118 nci maddenin 2 nci, 3 ncï fikralan ve 119, 120 nci maddeleri ahkồmını tetkik iedeceğiz.

aa) Her iki alacak da muaccel olmalidhr.

Takés iskat sebè'. olduğundan ve imuaccel hale gelmemiş bir borcun sukutu da mutasavver bulunmadığına göre, takas için ilk şart her iki alacağ!n muacceliyeti şartıdır. Aranan muacceliyet takas edil. me anıldaki muacceliyettir.

Alacaklardan biri mueccel olur veya taliki şarta bağlı bulunursa 
takas mümkün olłmaz. Taliki şarta bağli bir alacağın takasa tâbi olamaması, bu gibi akitlerde henüz borcun' ıdoğmamıs olması ve henüz doğmamıs olan borç hakkında muacceliyetin 'de mevzuu bahis bulunaimiyacağından nâşidir.

Mǘt'ekabil alacaklar ya akjit yapılidığ andan itibaren, veya, her ikisi de ecele tâbi iselèr bu ecillerin hululü ânundan, veya muacceliyet ıhbar vukuunda vâbeste ise bu ihbann yapıldığı anda muaccel olur. Alacaklan tevlit eden akit veya akfitler (sözlü olsun yazll sloun) de vâde ve tâlikî şart mevcut değilse, bu alacaklar bu akitler:n inşası tarihinden itibaren muacceldirler. Kaide budur. Hilâfını, iddia eden taral ispata mecburdur. Meselâ taraflardan biri ecel ve şart mevcut ołmamakla beraber muacceliyetin ihbar vukuuna bağlı olduğunu iddia ederse bunu ispat etmelidir.

bb) Heir iki alacağın aynı cinsten olması lâzımdır.

Thakas yalnız para borçlarn için muhdes bir öldeme usulü değildir. Ölçülebilen, tayttlabilen, ve sayilabilen ayn ainsten iki mütekabil alacak takas edilebilir. A, B den iki ton patatek alacakh olsa, B de (A) dan yarım ton aynı cins patates alacaklı olsa, takas kabildir. 'Buğday, ceviz, frndık, mısır, arpa ilh.. gibi mütekabil alacaklanın takası câizdir. Fakat misliyâtdan olmayan şeyler tak'ıs edilı̀nız. Mešlâ A, B den 200 dağlıç koyunu allacaklı olsa, B de A dan 100 dağhıç kloyunu alacaklı bulunsa takas câiz ideğildir. Zira, her ne kadar koyunlar (yani alacaklarr) ayn cinsten ise de her bir koyun gerek ağırlık, gerk sıhhat, gerek yün mahsulü ilh.... bakımındian ayn kıyimetde olalmayacağından takas kabili tatbik olmaz.

Takasın yalnız para borçlarna münhasır olmayıp sair mislì eşya için de câiz olacağı 118 nci maddenin 1 nci fikrasında șu suretle sarahatèn kabul edilmiştir : "Iki şahis kanşlliklı bir miktar mablâğı veya yekdiğ arine mümasil bașlka mallan birbirine borçlu olduklan takdirde her iki deyin muacciel ise ikli taraftlan he'r biri døytnini alaicağı ile takas edebilir". Görülüybr ki madde takalsı yalnız "bir 'miktar ımeblâğ" lâfzi ile tarif etmemektedir. Madde "yekdiğerine mümasil başka mallan" demekle birbirine nəvi ve kıymetçe müsavi olan şey alacaklan kast olunmaktadır ${ }^{5}$.

5) Bunun misallerini verdik. Bir iki misal daha ilâve zait olmaz: A, B ye 20 teneke Ayvalık zeytinyağı teslimine borçlu olsa, B den de 10 teneke (aym kiloluk) Ayvalık Zeytinyağı alacaklı olsa, 10 teneke zeytinyağı teslim 
cc) Takasta takias edilecek olan alacaklann miktar itibariyle müsavi olmalanna lüzum yoktur.

100 lira 100 tira ile takas edilebileceği gibi 5 lira ile de takas olunabilir. 100 kilo ceviz ayni cinsten 10 kilo cevizle takas edilebileceği gibi, 100 kilo aynı cinsten ceviz alacağı ile de takas olunabilir.

Takas edilecek olan alacaklar miktan ayn ise, takas olunan her iki alacak tamamen sukut eder. Aksi halde az olan alacak tamamen, çok olanı kısmen sakıt olur.

Para alacaklarnnda olsun, sair mümasil eşya alacaklarının takasinda olsun aynı kaideler câridir.

Takasta miktar itibiariyle müstaviatın şąt olmadiğına ait bu paragrafta takasın yalnız para alacaklarına münhasır bulunmadığı da dolayısiyle görülmüs olduğundan artık bu ciheti ayrı bir paragrafta tekrara lüzum yoktur.

dd) Takas alacaklardan biri münazaaln olsa bile kabildir.

Tak'as edilecek olan allacakllarin mutlaka ihtilâfsız olmasına lüzum yoktur. A, B ye borçlu olur, B itiraz eder, dava ikame lolunursa, B muhakeme esna'sinda A d'an evvelce mevcut, veya sonra hasil olmus muaccel alacağına karşı takas dermeyanı suretiyle mahkûmiyetten kurtulabilir. Zira alacağın münazaalı ølması takasın sair şartlarını ref etmez, hele muacceliyet şartma halel' 'getirmez.

118 nci maddenin son hükmü üzerinde dưrmak lâzumdır. "Mürurzamana uğramış bir alacak takas dermeyan edilebileceği zamanda mürur zaman ile sakit olmus ideğil ise onun da taka'sı dermeytan olunabilir."

Görülüyor ki mürur zaman prensip itibariyle takasa mânidir. Bu, doğrudưr. Zira mürur zaman borcu isklat eder. Takas sukuk sebebi olduğundan, esasen sakıt olmuş olan bir borcun ikinci defa sukutu mulasavver ve mümkün değildir.

Kaidemin istisna'sı, mürur zamana uğramıs blan borcun takas dermeyanı sırasında henüz mürur zamanla sakıt olmamıs bulunması halidilir. Su halde bu keyfiyet mürur zaimana, uğramı̧ lolan borçların ta-

etmekle borcundan kurtulur. B nin bunu reddetmesi kendisini mütemerrid k1lar. A, B ye 10 damacana taşdelen suyu borçlu olsa, B den aynı büyüklüktekỉ damacanadan 5 damacana taşdelen alacaklı olsa, takas câizdir. 
kas edilemiyeceği ḱaidesine bir istisna dahi teşkil etmez. Çünkü madde, mürur zamanla saknt olimus olan borcun henüz sakut olmadrğı and'a takas édilemiyeceğini nâtıktır. Yoksa münur zaman vâki olmaidian hiç takas derımeyan edilmemiş ikgen, vukuundan' sonra' takas dermeyanına cevaz vermuyor. Esasen böyle bir müsaiade kanunun müinur zamanla sakuit olan borçlar hakkknda koyduğu umumi kaiidelene de pek muhalif düsșerdi.

118 nci maddenin kaydledilen son hükmünün tatbìkî nelticeleri için bir iki misal araştrrmak lüzumsuz değildin : A, B den beş senelik müruru zamana tâbi olan 100 lira alacakh olsa müruru ząmanin dólmasına 10 gün kjalia $\mathrm{B}$ nin kenidislnden 'alacağg olan 80 lira muaccel hale gelse, takas dermeyan etse,' ancak B de olup tahlsil jedamediğ 20 lirasi mürur zamanla sakıt olur. 'A, B den 10 senelik müruru zamana tâbi 50 lira alacaklılı olsa müruru zamanın hululüne 2 gün kala B ye ödenmesi icap eden 80 lira blacu olsa, takas dermeyan ederek müruru zamanla sakıt olma tehlikesine maruz 50 lira alacağı takasla sakit olur, B ve 30 lira borcu kalır.

ee) Takas edilecek olan alackaklar arasunda irtibialt lâzam değildir. Menbai ne olutrsa olsun iki al'acak' takas edilebilir. Her ikisi de kanunıdan doğan biri 'kanundan, diğeri' akitten doğan' iki lalacak takas edilebilir. Takas edilecek alacakların menşe itibariyle yekdiğerine benzemesine de lüzłm yoktur. A B den karz akdinden alacakli olsa, B de A dan bey'iden' dolayı alaciaklı ßbulunisa takas yine câizdir.

\section{d) Takastan feragat:}

Taraflar mukavele yaparlarken bu mukaveleden doğacak olan alacaklannin takas edilemiyeceğini şart kioşabilitirler. A, B ye biorçludur. Ona bir şey satmak istiyor. Fałkat semenin eśki borçlł takaısına mâni olmak için müşteri $B$ den takastan frragat etmesini istiyor. Müşteri bunu kabul ederek mukavelede takasttan feragat ederse muteberdir. Takastan feragalt borçlu tarafindan yapilacak bir beryanla dahi blabilir. Hattâ mukavelede takasın mümkün olduğu yolunda bir kayit olsa bile sion raclan takastan feragat beyanı bu kaydı íptal eder 6 .

e) Takiası kabil olmayan allacaklar. 123/1

Bazı alacaklar alacaklının nzası olmadan takas edilemez ':

6) Filhakika müstevdanın tek borcu her talepte emaneti iadeden ibarettir. Emanetci ancak emanet ücretinden dolayı takas dermeyan edebilir. 
$\left.1^{\circ}\right)$ Hakssz iktisaba imevzu nakit ve takası kabil sair eşya veya bedellerinin talebine karșı takas dermeyan eedilemlez. 'A, Bi den haksız iktisapla 10 lira alsa veya 10 lira kiymetinde bir şey gasp etse, B bunun iadsini ister, yani A dan 10 lira alacakludr. A, B nin bu talebini vaktiyle kendisinden esasen alacağı olduğunu dermeyan ile takas dermeyanı suretiyle red ettiremez. Aksi hal şahsen hikakı hak memnuniyeti ihlâl edilmiş olurdu.

123 ncü Imaddenin 1 nci fikrast hükmmüne göre tevdî edillmiş olan sseylerle hile ile ahkonullmuş olan şeylerin iadesi talebine karşı da takas dermeyan olunamaz. A, B ye emanet folaulak 100 lira verse, billâhare $\mathrm{B}$ den istese, B, A dan meselâ karzdan dolayı alacaklı olsa, A nun emanet parayı talebi karşsısnda takas dermeyan ederek elmanet paranın iadesi zalebini red edip parayı alıkoyamaz.

$\left.2^{\circ}\right)$ Nafaka ve is üicreti gibi borçlunun gerek şahsına, gerek aillesinin iaşesine hâdim o'an mattubat tallebine karşı da takas dermeyanı câiz değildir.

A, B den 100 lira nafaka veya ücret alacaklisı olsa, talep etse, B ye 100 lira da borcu olsa, B, A nın nafaka veya ücreti olan 100 lirayı takasla itfaya kalkışamaz. Zirâ gerek nafaka gerek o hükümde tutulan iş ücreti korçlunun maddî şahsiystinin bekası için zarurì meblâğ olup, bunun takasla ıtfası şahsiyetin himayesi kaidesine aykırı düșerdi.

Maamafi, borçlu razı olunca bunun takası da câizdir. 123 ncü mad denin 1 nci f́krası takası kabil olmayan alacaklann alacaklnnı muvafakatı olunca takas edilebileceğine işaret ediyor.

$3^{\circ}$ ) Devlet, Vilâyet ve köylerin âmme hukukundan doğan alacakLan takasa tâbi değildir. Âmme hukukundan Devlet, vilâyet veya köyler lehine nịş'et eden alacaklann takasa tâbi olmaması, âmme alacaklavil ile âmme hizmeti ifa edileceği, ve âmme hizmetlerinin akamete uğramaması ve daimiyeti kaidelernin bir neticesidir. Şuhalde bir fert veya hususî hukuk hükmì şahsı devletin vergi, para cezası gibi âmme velâyetinden doğan alacaklann mutlaka bilfiil ödemekle mükelleftir. Devletde veya sa:r âmme hükmî șahılsan nezdinde mevcut alacakları ile takas ve mahsup edemezler.

7) Takastan feragat mukavelede münderiç muhtelif kayıtlardan anlaşllır : "nakden tediye" "bu akitten doğan alacaklar takas edilmez" "bilfiil .eda" ilh.. gibi ibareler hep takastan feragat addedilir. 
123 ncü maddenin 3 ncü bendi ancak âmme hukukundan doğan alacakların takas edilemiyeceğini işaret ettiğine göre, âmme hükmî şahıslannın hususî hukuk münasebetlerindlen doğan alacaklan takasla iskat olunabilir.

Takas hakkında umumî bilginin esaslarmi bu suretle kaydettikten sonra müteferı̈̈ik bazı ahkâmın tetkikine geçelim : Bu hükümler, 119, 120 ve 121 nci maddelerindedir.

aa) Kefalet halinde takas. Md. 119

Kefil borç ifa edilmediği takdirde asıl borçlu yerine geçerek alacaklıya edada bulunmayı üzerine alan kimse olduğuna, ve takas da ifa hükmünde bir müesseseden ibaret bulunduğuna nazaran, alacağın muaccel olduğu anda borçlu alacakh nezdindeki alacağın takas edebilecek vaziyetde ise, alacaklı kefili takip ediemez. Çünkü bu halide kefil 119 ncu maddeye göre "alacakliya tediyede bulunmaktan imtina edebilur". Bu imtina hakkı kefile mevdu, onun ühtiyanna metruk bir haktır. Bir mecburiyet de tahmil etmez. Binnetice kefil asıl' borçlunun takas dermeyan etmeye hakkı olmasına rağmmen edada bulunmus ise halefiyet ve dolayrsiyle hakk rücudan mahrum olmaz. Ancak takas hakkında bilgisi olan kefilin asll borçluya istitzan etmesi, takas dermeyan edip etmediği ve edip etmømek niyetinde Slup olmadığını öğrenmesi ihtiyat icabındandır. Aksi halde halefiyet imevzuu bahis olmaz; Kefilin alacakliya eda etmiş olduğu şey'i vücudu nihayete eren sebeb dolayısiyle haksız iktisap kaidelerince sahisen talep etmesi jcap veder.

bb) Üdüncü şahıs lehine taahhüt halinde takas Md. 120.

Takas ancak bunu dermeyan edlecek olan kimsenin zimmet ve matlubu ile, yani mameleki ile alâkah alacak ve borçlar için mü̈mkündür. Kimse başkasının mamelekine dahil alacağı kendi borcu ile takas edemez. İşte 120 nci madde hükmü bu esasa bina edilmiştir. Úçüncü şahıs lehine şartın temin ettiği allacak üçüncü şahsa aittir. Bu ïtibarla bu şartı kabul ettiren âkit bu alacağı diğer âkitde olan borcu ile takasa hakklı değildir. Fakat üçüncü şahıs lehine şartın borçlusu olan âkit bu şartdan doğan üçüncü şahsa karşı borcu üçüncü şahıs nezdindeki alacağı ile takas edebilir, bean şart ki üçüncü şahıs lehine şartı havi asıl akitde alksine hüküm mevcut ollmasın. Takastan evvelden feragat câiz olduğu cihetle (mad. 124), üçüncü şahıs lehine şartı kabul ettiren âkit mukaveleye şartın tevlit edeceği borcun takasa tâbi olamayacağı k'aydını da kabul' ettirmiş olabilir. 'Ancak takastan feragat âmme intizamı 
ile alâkalı olmadığından, üçüncü şahıs ile şartın borçlusu âkit, üçüncü şahıs hakkını kullanmak istediğini bizzat bildirdiği andan itibaren, feragata rağmen, takas mümkün hale inkilâp edebiliřs. Zira bu andan itibaren şartdan doğan alacak (imenfaat) kat'i surette üçüncü şahsın mamelekine dahil olur'.

Koşuian şarın icap ettirdiği borcun ifasın talep hakkı yainız şarłı kabul ettiren âkide münhasır ise ${ }^{10}$, üçüncü şahıs veya haleflerinin takasdan feragat şarı̀nı iptal ettịmeleri imkânsızdır.

cc) Borçlunun iflâsı halinde takas. Md. 121

Borçlunun iflâsı alacakllarn aleyhine olduğundan ve onlar için fevkal'âde bir hal' arz eylediğinden kanun bu fevkal'âde hal karşısında alacaklları thimaye etmek için 121 nci madde de takasın şartı olan muacceliyetten sarfinazar etmeyi uygun bulmuştưr : "Borçlunun iflâsı halinde alacaklilar, muaccel olmasa bile, alacaklanın müflisin kendilerinde olan alacă̆

f) Takasın nasıl yapilacağı :

122 nci madde takasın nasıl yapılması lâzım geldiğine dair hükümle takasın hükmünü ve imahfuz kalan bazı ahkâmı zikrediyor.

aa) Takas nasil yapılır :

122 nci maddenin 1 nci fikrası bu hususta şu hükmü sevketmiştir : "Takas ancak bck'çlunun takası dermeyan etmek kasdini alacakliya bildirmesiyle vâki olur".

Takăsın dermeyanı ve binnetice vâki olabilmesi için yegâne şart ,u maddenin kaydedilen hükmündeki şart değildir.

Takasin vukuu için evvelâ dermeyan selâhiyeti olmak lâzımdir. Takastan feragat edilmişse ${ }^{11}$, mücerret takas dermeyanı takasın vukuunu temin edemez. Takas dermeyanı ile takasın vukuu mümkün olabilmek için vaktiyle takastan feragat edilmemiş olmalıdır. Aksi halde

8) Lehine şart derpiş edilmiş olan üçüncü şahıs feragata rağmen takası kabul ederse takas mümkün olur.

9) 111 nci maddenin 2 nci fıkrası üçüncü şahsa halef olanların (mirascı) da borcun ifasını şahsen talep edebileceklerini beyan ettiğine göre, bunlar dahi feragate rağmen takası mümkün hale koyabilirler.

10) Md. 111/1.

11) Md. 124 "Borçlu iptidan takastan feragat edebilir". 
kendisine karşı takas dermeyan edilen alacaklının muvafakati, yani takastan feragatı iptal eden nzası lâzımdır.

Dermeyan selâhiyeti olan borçlunun takas niyetini alacaklıya müicerret bildirmesi kâfidir. Yani takas, hukukumuzda otomatik olarak vâki olur. Yani hâkim re'sen täkas icra edemez. Dermeyan edilince buna selâhiyetli ve vazifelidir $\mathrm{de}^{12}$.

Takas kasdinin alacakhya bildirilmesi için hususî bir şekil yoktur. Şifahien de muteberdir. Maamafih tevsiki kolaylaştrricı surette bildirmek ihtiyat icabıdır. Çünkü takas kasdinin bildirilmiş olduğunu ispet iddia edene aittir.

\section{bb) Takasın hükmü :}

122 nci maddenin 2 nci fikrası takasın hükmünü belirtiyør : "Bu takdirde iki deyin takas edilebilecekleri andan itibaren en az olan deynin miktarı nisbetinde sakıt olmuş addolunur.

Takas sukut sebebi olduğu cihetle hükmmü de bu fikradaki gibi olacaktır. Takasın tam ve kısmî sukut sebebi olabileceğine evvelce temas edilmişti.

cc) Gerek Borçlar Kanunundaki gelrek ticaret kanunundaki hesabı câri ile alâkalı olup borcun sukutu ile münasebettar ahkâm mahfuz dur; yani takas kaidelerine tâbi olmaz. Md. 122/3 13

C) Terdit (Novatio).

a) Yeni borcun ihdas ile eski borcu sukut ettiren bir muamele$\operatorname{dir}^{14}$.

Tecdit de sukut sebebi łoldưğundan yeni borrç eski borcun ferîlerini haiz olmaz. Çünkü eski borç sakıt olunca, sukutun umumî ve müßsterek neticesi olarak ,ona müteferri bütün hak ve borçlar da sakıt olur.

12) Mahkeme takas dermeyanı üzerine takasa mesnet olan alacağın mevcudiyetini tahkik eder. Alacaklı borçluya borçlu olduğunu ikrar ederse tahkikat lâzım gelmez. Hâkim takas şartlarını re'sen tetkik ve mevcut bulursa takası icra eder. Talep üzerine icra etmemesi bozmayı muciptir.

13) Takasın nevileri ve beynelmilel takas hakkında bakınız : Türk Hukuk Lugatı 1944, sahife 317, 318.

14) Eski borcun sukutu ile yerine yeni borcun kaim olmasıdır diye tarif münasip olmaz. Tecđit de evvelâ yeni borç doğmalı ve bu yeni borcun doğumu sebebiyle eski borç sakıt olmahdır. Bu itibarla tarifi "yeni borcun ihdası ile..." şeklinde yapmak münasiptir. 
Bhnnetice alacakil eski borcu temin eden şahsî ve ayni teminaitan müsiefit olamayaca ̌̆ dan müstefit olamaz. Görülüyor ki tecdit kaideten ve ekseriya alacaklınn aleyhinedir. Bunun içindir ki kanun (114) ncü maddesinde tecdidin vukuu için ilk şart olarak alacaklının eski alacaktan vaz geçereł bunun yerine yeni bir alacağın kaim olmasına rıza göstermesi keyfiyet: mevcuttur. Bu 114 ncü maddenin 1 nci fikrası hükmünden anlaşılan gartt:!: "Etorcun tecởidi akitten vâzih suretde anlaşılmak lâzımdır"'15.

Tecdit, borçluyu eski borçtan ibra eder; borçlu alacaklıya yeni biorcu iltizam eder.

Tecdit ifa yerine geçen edadan farklıdır : İfa yerine geçen edada borçîu alacaklıya kaıısı yeni bir borçla bağh değildir; eski borcun ifa sekli değişerek sukutu mevzuu bahistir : A, B ye 100 lira borçlu olsa, bunun yerine talhvil vermeyi veya bir saat teslimini teklif edip $\mathrm{B}$ de kabul etse, teslim ile 100 lira'llk borç sakıt olur ${ }^{16}$.

Tecdit sukut sebebi olduğuna ve sukut için her şeyden evvel mutalebe kabiliyetini haiz bir bol:cun mevcudiyetine lüzum bulunduğuna göre gerek talikî şarıa muallak, ggerek müruru zamana uğramış bbrçlar tecdit edilememek lâzımdir. ${ }^{17}$. Talikî şarta bağlı borç ancak şartın tahakkuku ille doğup, kabili mutalebe hale gelebileceğinden, sartın tahakkukundan evvel sukutu da hukuk tekniği cephesinden kabili müdafaa des̆ildir.

Her ne kadar "borç" tâbirinden müeyyideli ve müeyyidesiz (tabii borç) bütün borçlar anlașlır ise de sukut sebepleri yalnız müeyyideli borçlar için kabili istimal bir tâbirḍir. Mürur zamana uğramıs olan bir borcun tecdidi de doktrin ve tatbikatda aksi içtihad da olmasına rağmen, bizce ıümkün olmamak lâzımidır. Zira esasen mụ̈ıur zamana uğramış olan bir borç sakıt olmuş bir Worçtur. Sakit olmuş bir borcun bir daha sukutu mıntıkı olduğu kadar hukuk tekniğini de tatmin edici bir keyfiyet değildir. Diğel: cihthetten mürur zamana uğramış bir borcun tecdit edilebileceğin kabul etmek tecdidin tatbikî faydalarını da temin etmez: Taraflar tecdit anlaşmasında eski bırcun teminatı baki kalacaktır diye

15) Zımnı tecdit mümkün değildir. Binaenaleyh bazı müelliflerin zımn̂̂ tecdit muamelesi olabileceğine dair içtihadı kabule șâyan değildir : Arsebük, Borçlar IJukuku, üçüncü tabı, 950, Ankara, sa : 866.

16) Ifa yrine geçen eda tecdit mükmünde olmadığından, asıl eda mevzuunun taallûk ettiği akde müteferri hukuk devam eder. Kefil ve rehin varsa halel gelmez.

17) Aksi fikir : E. Arsebük, a. g. eser, sahife : 867. 
bir kayit koysalar dahi mürurzamanla sakrt olan borcun ferîleri ve meselâ kefalet, cezaî şart avdet etmez. Hülâsa mürur zamana uğramıs olan borçlann tecdide salih olup olmayacağı, bizce üzerinde durulacak mesâil zümresindendir.

Muteber olmayan Lłorçların tecdidi de muteber değildir.

b) Tecdidin neticeleri :

Tecdit alacaklı ve borçlu lehine olmak üzere neticeler doğurur.

1) Tecdidin alacakl lehine neticeleri :

Eski alacak noksanlardan ve teminat ve nakdî müeyyide yoklugundan kurtulur. 'A, B ile bir akit yapsa $\mid \mathrm{B}$ ' nin mzası fesada uğrarsa, A bu tehlikeyi nazara allarak (çünkü fesih olunabilir) bir sene içinde akdin tecdidini teminle bu akdi bu tehlikeden âri kılabilir. Meselâ temerrüd faizlerinden mütevellit bir alacak tecdit edilse alacakl için iki mühim netice hasil olur :

$\left.1^{\circ}\right)$ Faiz alacağı beş senelik mürur zamana tâbidir. Eski borç (temerrüd faizi) ${ }^{18}$ tecdit edilerek resülmale kalbedilirse müru|r zaman 10 seneye çkar.

$2^{\circ}$ ) Temerrüd faizinin faizi, faizi mürekkep memnuniyetinden dolay, işlemę. Halbuki tsmerrüd faizi tecdit olununca faizde getirir. Zira tecditle artık faiz resülmale inkilâp! ederek faizlik vasfı zail olur, binnetice, mürekkep faiz memnuiyeti kabili tatbik olmaz.

2) Tecdidin Kłorçlu lehine neticeleri :

Tecditle eski borcun teminat kendiliğinden kalkar. Rehin, kefalet, cezaî şar't, zaman rücu, yeni borcun fer'i olmaktan çkar. Eski borcu temin eden rehin kefalet, cezaî şart ilh... gibi ı borç dolayısiyle ihdas edilmiş olan teminat ve mukavelevî müeyyidat da mevcudiyet sebebini pâyi eder. Yeni borcu ihdas eden mukavelede hilâfı mukayyet ise hüküm öyle verilir. Ancak böyle bir şart eski borcu temin edien kefaletin devamına vesile olmaz; çünkü kefalet kefil ile alacaklının müstakil anlaşmasını icap ettiren bir akittìn.

Rethin isakıt olur. Binnetice yeni borç tesis blunurken eski borca

18). Tecdit için eski borcun mutlaka mukaveleden doğan bir borç olmasına Jïzum voktur. Kanundan haksız fiil ve sebebsiz iktisaptan doğan borçların dahi tecdidi mümkündür. 
teminat gösterilen menkulün yeni borç için de teminat olarak devamı şart edilmemiş ise, alacakli rehni, vücudu nihayete ermiş sebeble haksız iktisap kaidesi mucibince borçluya iade etmekle mükelleftirr. Hiç şüphesiz iade borçlunun talebine bağhıdır. Borçlu talep etmez, bir senelik mürur zaman hulûl ederse merhun üzerindeki mülkiyet hakkı sakıt olmaz, yani mülkiyet alacaklıya intikal etmez ise de, bu sukut, tecdit anlaşmasında, tasrih edilmemiş olmasına rağmen, merhunun yeni bơnç için de teminat olarak brrakılmıs olduğu. zımnen riza hükmünde tefsir, olunabilir. Her ne kadar tecdit için tecdit niyetinin mukaveleden sarahaten anlaşlması lüzumu 114 ncï maddennin 1 nci frkrasında "borcun tecdidi akitten vâzih surette anlaşılmak lâzim'drr" șeklinde sarahaten beyan edilmiş ise de, bu, bizatihi tecdit muamelesinin muteberliği içindir; eski borç teminatımın yenisine sirayetine dair şeraitin tesissi ile alâkalı değildir. Şu halde merhunun tecdide rağmen alacakhı yedinde brrakılmış olmasını yeni borç için de teminat olarak terk olunmuş bulunması şaklinde kabul yanlış olmaz ${ }^{19}$.

C) Tecdit teşkil etmeyen haller :

Mukavele ve borçta bazı tebeddülât vardir ki tecdit teşkil etmez. Meselâ alacağın azaltılıp çoğaltılması halinde tecdit değil, tâdil mevzuu bahistir. Bir borcun vadesini kaldırmak ${ }^{20}$ veya uzatmak dahi tecdit saynlmaz.

Bir borcun çŏgaltılması dahi tecdit değildiın : 100 liranın 150 iiraya iblâğ tecdit değildir. Tecdit olsa idi, kefaletin 100 liralık borç için devamı kả̉ul edilemezdi. Borç miktarının çoğaltılması çoğaltılan borcu temin eden kefaleti iskat etmez. Ve kefilin mes'uliyetini de artan nisbet dahilinde tevisi etmez ${ }^{21}$.

19) Borçlunun tecdide rağmen eski borcu temin eden merhunu alacaklıdan talep etmemiş olması onu yeni borç için de rehin olarak terkedilmis olmasından ziyade, emanet hükmünde olarak nazara alınması fikrine de sevk edebilir ise de, bu münasip olmaz. Zira emanet için ayrı bir akit lâzımdır. Halbuki şey vaktiyle rehin olarak terki nâtık bir irade ile devredilmiști. Bu iradenin baska bir hukukî muamele veya akitle iptal edilmemesi, merhunun alacaklı yedinde bırakılmasına razı olmak, sabık iradenin zımnen devamı hükmündedir.

20) Borc vadesi kalkmakla, muaccel olur, sakıt olmaz. Esasen tecdit için yeni bir borç ihdası da lâzımdır. Bu itibarla vadenin ref'i tecdit değildir. T.M. 4. H. Dairenin 30/4/1934 gün ve 654/621 s.k. da bu mealdedir.

21) Bunun için kefilin alacaklıya ayrı veya bir yazılı taahhütde bulunması icap eder. 
Mevcut bir borç için poliçe keşide ețmek veya senet tanzim etmeiz dahi tecỏit değ̣ildir. Mevcut bir borcun âdi veya ticarî senede bağlanması o borcu tevsik etmek veya tedavül kabiliyeti vermek içindir. Nihayet senede merbutiyet borcun aynen ve bütün ferîlerine şâmildir. Yani bu haklar sakıt olmaz. Maamafih borç senede raptedilirken tecdit şart olunabilir. 114 ncü madde bu ciheti ('Bununla beraber, bu hükmün aksine dair akdolunan mukaveleler muteberdir) seklinde ifade ediyor.

Yeni bir kefaletname imza etmek dahi tecdit değildir. Zira bu halde asıl borç mevtcudiyetine halel gelmez, hattâ asıl borç kefaletle müemmen idi ise, bu teminat dahi ssarsılmış olmaz. Aynı bir borç için yení bir kefaletname imza etmek kefaletle temin edilen asl borcun değil, eski kefalet borcunun tecdidi gibi düşünülebilir.

Tecdit, yeni borç bâtıl olduğu takdirde hükümsüzdür. A, B ye 100 lira borçlu iken tecdit anlaşması yapılsa, anlaşmada taraflardan birinin temyiz kudretinden mahrumiyeti sâbit olsa, eski borç devam eder. Eski borcun devamı bizatihi borıç için değil bütün teferruatı için mevzuu bahis olur. Zira, teıdit mevzuu yeni borç bâtıl olduğundan, eski borç ve binnetice teferruatı da sakıt olmaz.

Yeni borç taliki şarła bağhı ise, eski borcun talikî şarta bağlı olmasına lüzưm yoktur. Esasen taliki şarta bağh bir borcun tecdidine dok trin ve mevzu hukuk cephesinden imkân da mutasavver değildir. Zira tesdit, sukut sebebidir, bu sebeple mutalebe edilebilmek vasfı olan borçlar için mevzuu bahistir. Taliki şarta bağlı akitlrde borç henüz doğmamuşt 1\%. Doğmamıs olan bir borcun gerek tecdit, gerek, sair sukut sebebleriyle sukutu da düşünülmez. Mürur zamana uğramış bir borcun dahi tecdidi ilmen kabili müdafaa görünmez. Zira mürur zamanla borç esasen sakıt olmuştur. Tabiî borcuun Imutalebe edilebilmek vasf yoktur. Bu vasıftan mahrum hiç bir borç tecdit ile sakıt olamaz. Mürur zamana uğramıs bir borcun tecdit edilemiyeceği bu mülâhaza ile teyit olunabileceği gibi şu munzam izahla da desteklenebilir. : Tecdit muamelesinde taraflar eski borcun ferîlerini veni borç için dahi kabul edebilirler. $\mathrm{O}$ halde eski borca ait kefalet de yeni borcu temine devam eder. Eğer mürur zamana uğramıs olan bir borcun tecdidi mümkün olsa idi, sabık borçlu ile sabık alacaklının, Imürưr' zamanla tabiî borç haline gelmiş sabık borcu temin eden kefaletin devamını tecdit anlaşması ile temin edebilmeleri icap ederdi. Bu imkânsızıdır : Mürur zamana uğramış olan bir borcu sakıt olmadan evvel temin etmek için ihdas edilmiş bulunan kefaletin devamı için sabık kefilin alacaklıya yeniden kefaletname 
vermesi, veya eski kefaletnameye yeni borç için de kefaletin devam edeceğinin tasrihi icap eder. Halbuki tecditde eski kefaletin yeni borca sirayetini temin için kefilin aynca kefaletname vermesine lüzum yoktur ${ }^{22}$. Nihayet, mürur zamana uğramış bir borcun yeniden doğabilmesi borçlunun ihtiyarında olan bir şeydir. Alacaklının buna nza göstermesine lüzum yoktur. Zira esasen alacak vaktiyle mevcutdu ${ }^{23}$. Halbuki tecdit için iki tarafın anlaşması şarttır ${ }^{24}$

d) Tecditde ehliyet :

Tecdite alacaklının nza ıöstermesi lâzımdır. Her ne kadar tecdit suretiyle eski borç sakıt olup alacaklı akdin menafiinden tamamen mah. rum olmayıp yeni bir alacaktan faydalanır ise de, yeni borç eski borca nazaran alacaklyya daha az menfaat temin edici mahiyette olabilir. Bundan başka tecditle eski borcun alacaklı için müteferri menfaatleri ve teminat sakıt olabilir.

Bütün bunlar alacaklının mamelekini azaltan veya azaltmaya namzet muamelelerdir. Demek kj tecdit alacakh için nisbî de olsa haktan felragati mucip bir muameledir. Haktan feragat için, yani eski borçta mevcut olan menfaatlerin yeni borca sâri olmaması gibi iltizamî muamelede bulunabilmek için, tam akdî ehliyet, ye binnetice, tecditde alacaklının reşit ve mümeyyiz olması şarttır. Aksi halde tecdit bâtıl olur, eski borç devam eder. Tecdit muamelesinde alacaklı mümẹyyiz olup reşit olmasa, bilâhare rüşı tekemmül etse, ve alacaklı reşit değil iken yaptığı tecditde ehliyetinin bulunmadığına vâkuf olmasma xlağmen sükût etse, bu, eski tecdit muamelesinin muteberliği yolunda tefsire mahal veremez. Zira tecdit zimnî ollmaz. Bu cilheti kanun 114 ncü maddiesinin 1 nci bendinde söyle tasrih ediyor : "Borcun tecdìdi akitten vâzıh şekilde an-

22) Yeni borcun miktarı - artmış ise, kefilden ancak artan kisım için kefaletname istenebilir. Yoksa kefil eski borç miktarı nisbetinde mes'ul oulr; fakat bu mes'uliyet için yeni borç içinde kefalet taahhüdünü tekrara lüzum yoktur.

23) Borçlu mürur zamana uğramıs bir borcu ödeyeceğini ikrar etse, asıl alacaklının bundan haberi bile olmasa, mirasçlardan bu ikrara istinaden alacağı tahsile hakkı olur. Borçlu bunlara karșı müteveffa selef alacaklının ikrara muttali bulunmadığını, binnetice, muvafakatı olmadığından bahisle defj de bulunamaz.

24) Bụ saylan ve izah edilen esbaba binaen mürur zamana uğramıs borçların tecdit ile yenilenebileceğini müdafaa eden doktrine bizce iştirak güçtür. 
laşılmak lâzımdur". Binaenaleyh, alacaklının tałm akdî ehliyeti iktisabı halinide gayn muteber tecdit muamelesinin yenilenmesi, yani alacaklı ile borçlu arasında eski borcun tecdidine dair yeni bir anlaşmanın yapılması zaruridir.

e) Tecdidin nevileri :

Buraya kadar tecdide müteallik kaydedilen kaideler ve izahat hep borç melvıuundaki değiģ̧me dolayısı ile vâki telıdide aittir ${ }^{25}$.

f) Tecditle ifa yerine geçen eda ałlasındaki fark :

Tecdit ifa yerine geçen eda ile karıştırılabilir. Aralanndaki farklar şunlardir :

1) Tecditde eski borç sakut olur. Ifa yẹine geçen edada eski borç sakıt ollmaz. A, B ye $\mathbf{1 0 0}$ lira borçlu iken bunun yerine bir masa vermeyi alacakhya kabul ettinse, 100 lirayi teminen kefil bulunsa, kefalet sakıt olmaz. Masa verilemedigi zaman alacaklmun 100 lirayı istememesi için hiç bir sebeb yoktur. Eğgln ifa yerine geçen eda taahhüdü iskat sebebi olsa idi bu netice hasll olmazd. Tatbikatda ifa yerine geçen eda derhal vâki olur. Taahhüt şeklinde olmaz. Aksi halde tecdidle pek farklı olmazd. Ifa yerine geçen eda mükellefiyeti kefile de sâri olur. Kefilin ifa yerine geçen eda mevzuunun değeri, yerine ifa olunması taahhüt edilen borçtan fazla olmadıkça nakden zâmin olması icap eder.

2) Tecditde borçlu alacaklıya karşı taahhütden kurtulmuş olmaz. Yeni borçla bağlıdır. İfa yerine geçen eda da asıl borç eda suretiyle sakıt olmuş olur. Fakat, hilâfı sart edilmemiş ise, (1) no. da kayd edildiği gibi, ifa ile alâkahı teminat (aynî sahsî) ve borcun ifa ile alâkalı edilmis idi ise, bu 100 lira yerine teslimi kabul edilmis o'an masanın teslim edilmemesi veya geç teslimi veya teslim mahallinde tes'im edilmemiş olması halinde borçludan yine talep ounabilir.

g) Hesabi câri. Md: 115.

Hesabı câri de tęđide mahal verir. Bunu anlamak için hesabı câri hakkında umumí bir fikir edinmek zarurídir.

25) Tecdit üçtür: ya borcun mevzuu değişmekle, veya alacaklının veya borçlunun değişmesiyle vâki olan tecdit. Bu sonuncular alacağın temliki borcun nakli muameleleriyle hasıl olur; Tatbikattta tecdit borç mevzuundaki değișme ile olanıdır. Diğerleri hakkında alacağın temliki ve borcun nakline dair kaideler tatbik olunur. 
Boł:çlar kanununun mezkûr maddesi hesabı câriyi yalnız borcun tecdit suretiyle sukutu bakımından zikr etmiş, müessesenin mahiyet vє şartlarına tenas eylememiştir. Binaenaleyh, müessese hakkında umumî bilgi edinç̉ilmek için ticarelt kanunu ahkâmından istianeye ihtiyaç zaruridir.

1) Hesabı cârinin tarifíi :

Borçlar kanununda hesabı cầi için mahsus bir tarif olmadığı cihetle ticaret kanununun 782 nci maddesindeki tarif nazara alınmak lâzı́m. dır : "iki ફ̧ahsın"6 yekdiğerine ita edecekleri nukut ve mülkiyeti kabili devir olan her nevi emva'dien mütevellit matluplarmı alel' infirad talepten mütekabilen sarfnazaly ve bunlan kalem kalem zimmet ve matlup şekline ifra ile hesabın kat'ından hâsıl olacak bakiyeyi talep selâhiyetine dair aktedecekleri mukaveleye hesabı câri ntlak olunur".

Hesabı câri mukavelesinin müddeti mukavelede gösterilir. Bu müddet ya muayyen bir meblâğa kadar muamelât yapłmak veya muayyen bir tarih zik:ii ile tâyin olunur. Mukavelede sarahat yoksa örfü adet veya işin mahiyeti ile de tâyin edilir. Ticarî örfü âdetde blhassa 6 ay ve 1 senelik müddet'er kabili tatbiktir.

Hesabı câri mukavelesinden evvelki hesaplar hesabı câriye dahil olmaz; yani hesabı câri muhtevasına dahil olacak alacak ve borçlar bakımından makable şâmil o'maz. Bu kaidedirr. Hesabi câri mukavelesinde hilâfına şart muteberdir. Ticaret kanununun 783 ncü maddesinin 2 ro. lu bendinden bu anlaşl maktadır. Borçlar kanununun 115 nci mad. desi bu hususta sakittir. Zira hesabı câri 'Borçlar kanuna mïnhasıran tecdit dolaysstyle bolçlann sukut sebebleri cihetinden dahil olmuştur. Binaenaleyh tarafların hesabı câri anlaşmasında makable șumul prensibini kabui etmis olmalannın borçlar sahasında da makbul olmamasına hic bir ssbeb yoktur. Yekdiğ̈arine sık ödünç veren ve ödünç alan eşhası âdiyenin böyle bir anlaşma yãpmalan uzak, fakat mümkün ihtimaldir.

Borç'ar kanununa nazaran hesabı câri sütunlarna müteaddit kalemle in mücerrế kaydedilmesi tecdit tevlit etmez: "Muhtelif kalemle. rin bir hesabı câriye mücsłrret kaydedilmesiyle borç tecdit edilmiş, olmaz". 115/1. Ticaret kanununda ise hüküm aksinedir : "... hesabı câriy kayd edildiği halde hilâfı şart edilmedikçe bu matlup tecdit 'edilmiş

26) Hesabı-câri en çok hükmi şahıslar arasında cereyan eder : iki şirketin alış veriş ve muamelatı Banka muamelatındaki hesaplar böyledir. 
olur" : 783/2. Demek ki tịcarî mevadda aslolan mücerret kaydın tecdidi tazammun etmesidir.

Hesabı câri mukavelesi kaideten mabadına şâmildir 27. Yani mukaveleden sonraki alacak ve zimmetleri ihtiva eder. Mukavelede hangi alacakların hesaba dahil olacağı, hangilerinin olmıyacağı da tâyin olunabilir.

Hesabı câride tecdit ancak 115 nci maddennin 2 nci fikrası mucibince ivâki olur: "hiesap kesilip de diğger tarafça kabul' edildiği takdirde deyin tecdit edilmiş olur'".

Hesabın kesileceği an hesabı câri mukavelesinin müddeti ile belli olur. Maamafih taraflar mukaveledeki müddetten evvel dahi hesabın kesilmesini her zaman karşılıklı olarak kabul edebilirler.

Mücerret hesap kesilmesi tecdit için kâfi değildir. Hesap kesme sonunda hâsıl olan meblâğ hakkında ihtilâf olmałmak lâzım'dır. 115 nci madde bu ciheti "... hesap kesilip de diğer tarafca da kabul edilmiş olduğu takdirde" diyerek ifade ediyorr.

2) "Hesabı cârinin' hükmü :

Fîlesabı cârinin hüküm ve neticelerini şu suretle hülâsa etmek mümkündür:

- $1^{\circ}$ ) Hesabı sâriye dahil olan her alacak müddel. sonuna kadar talep olunemaz. Zira bu alacak hesabı câri sonuna kadar, yani hesabin kesilmesi icap eden âna kadar borçlunun mamelekine d'ahildir. Ticaret kanununun 783 ncü maddesinin 1 nci fikrası bu keyfiyeti şu tarzda ifade ediysor : "Hesabı câri zımnında alınıp mathuba kaydolunan emvallin mülkiyeti alan tarafa intikal eder". Bu hüküm alacağın borçlu mamelekine dahil olacağına d’ain olan iddiayı da kanunen teyid eder.

$\left.2^{\circ}\right)$ Hesabı câriye dahil nakit /ve etnvalin haczi câizdir. Ancak haciz hesap ssonunda borçlunun çıkacak alacağ kabili tatbiktir. Demek oluyor ki henüz hesap rereyan ederken hacze tevessül ihtiyatî tedbir mahiyetinde bir muameledir. Hesabın devamı müddetince hacizin fiilen imkânsızhğı, hesap devam ettiği müddetçe mütekabil alacaklann muacceliyet hassasmdan mahrumiyetinden ileri geldi-

27) Maamafi mukavelede hesaba dahil alacak nevileri peșinen gösterilmiş olsa bile bu kayıt, tarafların sonraki anlaşmalarına mâni teşkil ełmez. Yani taraflar mukavelenin hesaba dahil etmediği alacakları da sonradan dahil edebilirler. 
ği gibi, bortçlunun alacağının alacaklanın mamelekine dahil bulunduğu kaidesinin de bir neticesi addolunabilir.

$3^{\circ}$ ) Hesabı câriye mukayyet alacak tecdit edilmiş saylmaz. Md. 115. Fakat ticarî hesabı cârilende hükǜm aksinedir. Bunu Borçlar Kanunundaki hesabı câri ile Ticaretdeki hesabı câriyi tecdit bakumundan kıyas ederken gömeceğiz. Kaide kaydedildiği gibi ol'duğundan, hesaba dahil edilmekle borç, rehin ,veya kefalet veya her ikisi ${ }^{28}$, ve sair müteferri borçlar sakıt olmaz.

$4^{\circ}$ ) Hesabı câri neticesinde matlup ve zimmet muhtevası arasındaki mahsup neticesinde hâsl plan borç (alacak) yeni borcu teşkil edern, ve kalemlerin temsil ettiği alacak ve borçlar yerine kaim olduğundan onlar têcdit edilmiş olur.

\section{farkı :}

$\left.5^{\circ}\right)$ Borçlar hukukundaki tecdit ile ticaret hukukundaki tecdidin

Her iki kanunda tecdidin benzerliği tecdidin mahiyeti ve bakiyenin gördüğ̈i muamele ve arz estiğgi hüviysttedir. Filhakika 115 nci madde "hesap kesilip de iki tarafea da kabul edilmiş ise deyin tecdit edilmiş olur" diyor, ve ticaretkanununun 783 ncü maddesinin 4 ncü fikrası aynı şey’i "zımmet ve matlubu teફ̧kil eden mebâliğ vekdiğerinden tarh c’unduktan sonra bakiye vacibüttediye blur" şeklinide ifade ediyort.

Borçlar kanunu ile Ticaret kanunu arasındaki fark hesabı cârinin tecctitle alâkası cihetindendir : Borçlar kanununda kalemlerin hesabı câriye miťserıet nakli tecdit değildir. 115 nci maddenin 1 nci fikrası bunu "muhtelif kalemlerin bir hesabı câriye mücerret kaydadil nesiyle borc tecd' edilmis olmaz". tarzında ifade veriyor. Ticaret kanununun 783 ncü maddesinin 2 nci fikrasında ise "mevicut bir matlup tarafeynin nzası ille hesabı câriye kaydedilldiği halde hilâfı şart edilmedikçe, bir matlup tecdit edi'miş olur". denilməktedir.

Görülüyor ki ticari mevadda borcun veya alacağın hesaba mücermet duhulu kaideten tecdittir. Tecdit olmaması için akksinı sarahat lâzım$\mathrm{d} \mathrm{x}^{29}$.

Hesabı câri ile takasın farkı.

28) Bir alacak aynı zamanda hem aynî hem şahsî teminatla müemmen hale getirilebilir.

29) Bu sarahat ya tecdit mukavelesinde peșinen mevcuttur, veya bilâhare, hattâ müstakil bir akitle de temin olunabilir. 
1) Hesabı pâride de mütekabil alacak ve borçlar vardır. Błu ba. kımdan itakasla kanş̧ırlmasa bile münasebet ve farkı teemmüle sevk eder. Hesabı câri taḱas şerraitine tâbi değildir : hesaba dahil kalemilerin (alacak ve borçların) aynı cinsten olmasina ve herbirinin ayn zamanda muacceliyetine lüzum yoktur. Takasda müstakil ve mutalebe edilebilen borç ve alacak mevcut olduğu halde hesabı câride kalemlerin temsil ettiği borç ve alacaklarda bu vasfflar yoktur. Nihayet hesabı câri tecdide mahal verdiği halde, takasda borç sakıt olur. Takas kısmî olsa bile mütebakî alacak tecdit iedihmış alacak hükmünde değildir. Meselâ 100 lira ile 130 lira takas eddilse, 130 lirayı temin eden aynî ve şahsi teminat bakiye 30 liranın teminatı olarak kalır.

2) Alacaklyyı tatmin etmeyen sukut sebepleri :

$\mathrm{Bu}$ ssukut sebeblen üçtür.

A) İbra

B) Borç ımevzuunun sonradan jimkầnsız hale gelmesi

C) Mürurzaman

A) İbra (Remise Conventionelle)

İsviçre kłanununun 115 nci maddesi 'Borçlar hukukumuza dahil edilmemiştir. Bizce bu, zuhul eseri olmak lâzımdır. Zira bir kanunun ar.a kaide ve müesseseleri adapte edilirken ibra gibi tatbikî ehemmiyeti bariz bir ımüesseseden sarfinazar münasip olmazdi. Borçlar kanunumuz kendine hâs bir ibra müessesesi de tanzim etme miş olduğundan müessese hakkında bilgi edinebiłmek için gọ!ık modern, gerek eski hukuk$\tan$ istiane zarurì olduğu gibi doktrine de temas lâzımdır.

\section{a) İbranm tarifi :}

Ilbra, alaicaklının ivazh veya ivazsız olarak alacağının tamüumından veya bir kısmından borçlu lehine feragat etmesi, daha doğrusu itfa ed:lmiş ggibi kabul eylemesidir. Bu takdirde borç kısmen veya tamamen sakut oilur. Ivazh, ivazsiz ibraya birer misal verelim ; A, B deki 100 lira alacağından ancak yarısını kabul dile mütebakisini ödenmiş farz etse veya mütebakisi için borçluyu takip etmemeye razı olsa ibra ivazsız kısmi ibradır. A, nun 'B de 100 lira alacağ kira ile kíralaması şartiyle 100 lirayı istemekten vaz geçeceğini bildirse, mükelleafiyet tahlmil eden iblna mevzuubahis olur. Dikkat edilecek ci- 
het, borçluya tahmil edilen mamelekî mükellefiyetten alacaklının değil üçüncü şahsın menílaattar olmasıdır. Alacaklıyı tatmin derse kısmî ibra mevzuu bahis olur : A, B den 100 lira alacaklı plisa, 20 lira kiymetinde bir şey'e mukabil 100 lirayı istemeyeceğini bildirse, bu, 80 liralık ibra teşkil eden. Alacaklının ellde ettiği menfaatin nakden kıymeti alacağa muadil veya onu mütecatviz olsa bu takdirde ibra mevzuu bahis olmaz. Meselâ A, B den 1000 lira alacaklı olsa, B nin téklifi üzerine veya kendi teklifi ille $B$ den knymetleri 1000 veya 1500 lira tutan iki ata mukabil allacağın valebinden viaz gieçse, ibra değill, ifa yerine geçen eda mevzuu bahis olur. Atlann knymeti 1000 lirayı mütecaviz olsa bile borçlu mameileki lehine, allacaklınınki aleyhine birl netice hasıl ol'madığından ibra volktur. Son misalde bila'kịis alacaklının mameleki ar'umıstır. Zira alaca,ğından fazla değgerdeki ata alacağa karşılık sahip olmuştur.

libra bir akitle olur. Mehaz kanununun 115 nci maldesi bunu sarih olalrak beyan ediyor.

Bu akitde ibra edecek ollanın, yani alacaklınn tam akdî ehliyete sahip olması icabeder. Zira ibra ile mamelekinde eksilme hasil ollur. Borçlunun ise 'mümeyyiz olması prensip itibariyle kâfidir. Ziraibra anlaşması kaicleten her iki tatrafa vecibe tahmil eden bir akit değildir, borçluyu zenģinleștirici bir muameleldir. Binnetice mücerret mümeyyiz olmak ibra icıabına kabull beyan için (kâfidir. Meselâ gayrı reșit, fakat mï̀meyyiz bir kimse haksız fiil işleyip 1000 lira tazminata mahkûm olsa, mağdur bu borçtan ibra edip fâilin de bunu kabul ettiği sâbit olsa, ibra muteber olur.

İbra borçluya mükellefiyet ta'hmil ediyorsa, blorçlunun tam akdı ehlityète stahıp olması lâzımdır. Istersie mükellefiyet ibra ile sakıt olacak ollan borca nisbetle az bir Imebiâğ veya maisrafa tekabül etsin hükünı böyledir. Bu, gayrı mümeyyizlerin bizzat iltizamî muamelâta dahil olamayacakları kaidesinin netıcesidir.

İbradia icap ve kabulün tarzına da termasa mahal vardır : Alacaklının ibra kasdi 'sarih veya zımnî olarak' borçluya vasıl olmak suretiyle izhar edilmis olmalıdır: Senede ibrayı natık bir kayıt düşürülmesi veya bir kaç 'kişi nezdinde borçlư ida mevcult olduğu halde senedin yırtılmak, veya sair suretle ibra kasdiyle iptaki hep ibra! için ica'p halleridir. Alacaklının borçludan uzưn zaman haklanın talep etmemiş olmasını Von Thur ve onu takip eden Arsebük ${ }^{30}$ zımnî ibra addetmekte iseler de

30) A. Arsebük, a. g. e. sa: 859 . 
bu, ibra licabının borçlunun ittılaina vukuf kaide Ive aslî̀ şartı ile tezat teşkil ledter. Halttâ o kadar ’ki alaraaklı senede meşruhiat suretiłyle borçluyu ibra letse ve fakat ķeyfiyetten borçlu : haberdar edilmese ve ölse, mirasçlalri bu sarih ibraya istinatia blorcun edasindan kurtulamazlar. Zira ibra reddetmemekle tekemmül eden bir muameledir. Şu halde ibrayı nâtık iradenin borçlunun ıttılain vusulü, şartı aslîdir. Ancak bu suretledir ki kabull veýa meddetmenis solmalk keyfiyetil mevzuu bahis olabilir.

İbra icabının kabulü için dahi bir şekli mahsus yoktur. Sarih veya zımnî kabul olabileceği gibi |ekseríya reiddețmemek, yani mücerret sükût kabule tekabül leder. Fakat ivazh veyia mülkellefiyetlì ibra teklifleminin Isarih veya zımnî kabule iktiranı iktiza ełer. Bu halde icap ve kabul kaildelerince hükmetmek münasip blur.

İbra edilecek olan borcun libra ânında mutlaka 'muaciçel' ollimasina lüzum yoktur. Binnetice ecele bağh bir borç dahi ibra ile sakıt olur. Ancak talikî şarta bağhl bir borcun' ibbrası câiz 'olmaz.

Zira bu gibi akitlerde sairt tahakkuk eitmeden evvel borç mevcut değilldir. İbra bir biorcun sukut sebebxi olduğunia ve borcun sukut iedebilmesi için kâmil bir bortç şeklinde mercudityetine lüzù m bulunduğuna nazaran, talikii, şarta muallak akitlende henüz nüve halinde bulunan borcun "brası ìmkânsızdır ${ }^{31}$.

Ecele bağh borçların ibrası lecelìn hululünden itiblaren ıdeğill ibra anlaşması anından hüküm ifade eder. Zirra ibra, mürưr załınanın hilàfına iollarak dava hakkını değil bizatihî hakkı ref 'edien b’ir sukut ssebebüdir. Şu halde ibrayıı ecelin kabulü ile muaccel olacaktrr mülâhazası ile ecele bağh borçlarda ecelden itibar etmek düşüncesi vâridi hâtır olmamalıdir.

b) Ibra mameleki azaltikı bir imuamele olduğunidan yapacak olanın ibra ile iskat edeceği hak üzerinde münhasır tasarruf selâhilyeti bulunmak lâżmilır. Bu kjaidenin riki netceisi şudur :

1) İbra ile iskat olunacak olan alacakda iki alacaklının müşterek hakkı varsa her ikisinin nzası icap eder. Meselâ ailenin mal birliğine girecek olan bir alacağı koca ibra edemez.

31) Şu halde henüz doğmamış bir borcun, ileride doğması muhtemel ve meşkûk bir borcun ibrası mümkün olmaz. Bazı müellifler aksi fikirdedir : A. E. Arsebük a. g. e. sa: 859 . 
2) Alacak üzerinde fer'i hukuk mevcut ise bu hukuk kendisine ait olan üçüncü şahısların nzası lâhik olmadıkça rehin, intifa gibi haklarla takyit edilmiş alacak münhasıran alacaklının nzası ile iskat olunamaz ${ }^{32}$.

3) Vekil dahi ibrayı alacaklı müvekkilden mahsus selâhiyet almaḱla ibra edebilir. Maamafih icazet selâhiyetsiz temsil ile vâki ibrayı muteber kilabilir ${ }^{33}$.

İbra bir akit olduğu cihetle talikı veya infisahî şarta bağlı olarak yapılabilir. Taliki ve infisahî şartla yapılan ibralar şartın tahakkuku anından itibarien hüküm ifade ederler, yani borç o vakit sakıt olur. İnfisahî şarta merbut ibralar da şart tahakkuk etmedikçe borçlu edaya zorlanamaz. Şartın tahakkkuk etmeyeceği kat'iyetle sâbit olursa artık borç sakıt olur $^{34}$.

c) İbranın şartlan :

İkıłra muteber olabilımek için alacakh ve borçlunun anlaşmış olmalan icap eder. Demek ki ibra bir akitle hasil olur.

d) İbranın şekli :

İbra mukavelesi bir şekle tâbi midir? İsviçre hukukunda ilerde görüleceği gibi hiç bir şekle tâbi değildirn. Fakat bazı müellifler ${ }^{35}$ esasen şekle tâbi akitlerden doğan borçlarnn da o şekle riayetle ibra edebileceğ̆ mealinde fikir beyan etmekte iseler de, bizce Türk hukukunda ibra, isterse borç şekle tâbi akitten doğsun, aşağıdaki esbaba binaen hiç bir sekle tâbi olmamalıdır:

1) Her şeyrden evvel Türk Borçlar Kanununda ibra müessesesi mevcut olmadığına göre ibranın şekle tâbi olup olmayacağı meselesi 12 nci maddeye istinatla değil 11 nci madde hülkmünce halledilmek icap eder. Madem ki kanunda ibra müessesesi yoktur, kanun ibra anlaşması için bizzarur bir şekil de tâyin ve tesbit edemez.

12 nci madde ibraya teşmil edilemez; çünkü ibra tâldil hükmünde

32) Bu, ibranın borcun sukut sebeblerinden olușu ve sukutuun ferilere de şâmil bulunuşu kaidesinin neticesidir.

33) A. E. Arsebük, a. g. e. sa: 859.

34) A. E. Arsebük, a. g. e. s: 859.

35) F. H. Saymen Borçlar hukuku Dersleri, C. I. İstanbuI, 1950, s: 562 Kemaleddin Birsen, Borçlar hukuku dersleri, İstanbul, 1954, s: 621. 
değildir. A, B/ den 15 lira alacaklhdır, B ibra ile bonçtan kurtuluyor yani akit icra edilmiş farz olunuyor. Mevzuu icra edilmiş olan akit hükmünü icra etmiş ve binnetice tadile mevzu ve müstehak olmaktan çkmıştır. Mevzu mevcut olsa idi, tâdil düişünülebilindi.

Kısmî ibra dahi tâdile tekiabül etmez. Binnetice kısłmî ibra halinde dahi borç şekle tâbi bir akitte doğmuş olsa bile, şekil şart değildir. Bu cihet ibra muamelesinin tekemmülüinden evvel mukavelede tâdilin mü̈mkün olmayacağ hakikatı ile de ispat olunabilir : A, B dien 50 lirra alacakkı olsa, B yi 25 liradan ibra etmek istese, B bunu evvelâ kabul edecektir; etmedikçe A nin senetdeki 50 liray 25 liraya tahıvili (yani tâdil) hiüküm ifade edemez. B 25 liray tekran 50 liraya tahvil ettirebilir, yani senede eski halini verdirebilir. Görülüyor ki ibra tâdil muamelesine tekaddüm eder; binaenaleyh kısmî ibrayı da tâdile benzetmek câiz değildir.

Bu kısa izahatın neticesi şudur: Her borç hiç bir şekle tâbi olmakstzon ibra edilebilir. Borç senede merbut olsun olmasun thal böyledir. 1000 lirahk bir senedin ibra kasdiyle yurtlması, veya alacakl tarafindan ibra meşruhthat ile iptali veya borçluya iadesi; kefalet senedinin de kefilin mühmanaat etmemesi sartiyle ayn muamelelere maruz kalması hep ibrayı ifade eder.

İbranın bir akit olduğu ve bu akdin, ibra edilecek olan borç şekle tâbi akitten doğsa bile, hiç bir şekle tâbi olmadığı cihetleri mehaż kanununun 115 nci maddesinde de açıksa beyan edilmiştir. 115 nci maddle aynen şöyledir: "Il n'est besoin d'aucune Forme spéciale pour annuler ou réduire eonventionnellement ${ }^{36}$ une créance, lors même ğue, d'après la loi ou la volonté des parties, l'obligation n'a pu prendre naissance grace à Certaines conditions de forme :

Bir alacaiğ mukavelevî olarak tenzil etmek için, borç kanun veya taraflann iradesi ile bazı şekil şartlariyle doğmuş olsa bile, hiç bir husu. sî şekle lüzum yoktur.

Bu tarifi havi maddenin Borçlar kanunumuza almmamıs ol:masın senetli bir borcun şifahen ibra edilemiyeceğinin ispatı cihetine gidilmemesi şahit istimaına cevaz verilmemesini temin için olduğunu beyan eden bazı noktai nazar var ise de, bu noktai nazar, kanunumuzun ibra hukukunda tam bir sükût ihtiyar etmesi sebebiyle kabili tatbik olamaz. Kanun hiç bir yerinde ibranın şekle tâbi olup olmadığına zımnen dahi te.

36) Conventionnellement tâbirinden ibranin mukavele ile olacağı anlaşlilyor. 
mas etmemiştir. Tatbikatçı kanunun bin mesele hakkında takip ettiği maksadı kanunun sarih veya zımnî maksadından anlamak mevkiindedir. Aksi hal içtihat ile hükme ve bu arada gerek mukayeseli hukuktan gerek doktrinden istiane ile harekete tevessüle imkân verir. İbra kısmî olsun, küllì olsun akdin tâdili mahiyetinde olmadığından, kıyas yoluyle şekle bağlı akitlerden bulunduğunu iddia da imkânsızdır. Şu halde mutlak sükûta rağmen ibranın 115 nci maddeden mülhem olarak hiç bir şekle tâbi olmadığı içtihadına sâdık kalmakta bizce isabet vardır. Türk kanun vazunın kasdi ibranın şekle tâbi olacağı şeklinde bulunsa idi bu maksadı ifade eden bir ibarenin mevcudiyeti mutlaka icap ederdi.

e) İbra çeşitleri :

Ibra ya borcu tamamen iskat eder veya tenzil eyler. Bifinci halde tam (küllì) ibra, ikinci halde kasmî (cüz'i) ibra mevzuu bahistir. Bir şahısta olan bütün bir alacağın takibinden vaz geçmek ${ }^{37}$ tam, bir kısmı hakkında takibte bulunmamayi ${ }^{38}$ kabul etmek kısmî ibradır.

İbra bonçlunun zimmetinden tam beraati cihetinden de ikiye aynlır:

1) İbrayı iskat

2) İbrayı istifa

$1^{\circ}$ ) İbrayı iskatta alacaklı borçluyu borcun bir kısmından veya tamamından beraat ettirir, ve meselâ borcu kısmen veya tamamen talepten feragat eder, borkçlu da bunu kabul eylerse borç sakıt olur. İbrayı iskatda alacaklı fiilen tatmin edilmediği gibi tatmin edilmiş olarak da meefruz değildir.

$2^{\circ}$ ) İbrayı istifa da ise alacaklı alacağının bir kısmını alır, hepsini tahsil ettiğini beyanla ibrada bulunur. Veya hiç tahsil etmez. Bütün alacağın tahsil edildiğini nâtık sened verir. Her iki halde de ibrayı istifa mevzuu bahistir ${ }^{39}$. Bu çeşit ibra borçlu için izzeti nefsi daha tatmin edicidir. İbrayı iskat da borç sakıt olur ise de borçlu alacaklıya karşı hiç

37) İbra için alacağın mutalebe kabiliyeti mevcut olmak lâzımđır. Ecele bağlı borçlarda talep edilebilmek hassası vardır, ancak muayyen zaman için muallâktadır. Şu halde ibra mutlaka muaccel alacaklar için câri olmaz: Teferruat için ibranın şartları bahsine bk.

38) Feragat demek doğru değildir. Zira feragat için hak sahibinin iradesi kâfidir. Ibrada ise akit lâzımdır, yani borçlunun kabulü şarttır. Teferruat: Şakir Berki, Borçlar hukuku, Ankara, 1956, Kitap.. I, s: (354)

39) İbrayı istifa da bir nevi ikrar vardır. Alacaklının borçludan borcun tamamını alması veya bir kısmını alıp mütebakisini almamış olması hepsini tahsil ettiğini ifade eder. 
değilse ahlầken borç |münasebeti ile bağh̆darr, onun minnettan olarak kalır. Ibrayı istifa da ise tam bir beraati zimmet, binnetice, sahsiyetin tam bir himayesi mevzuu bahistir.

İbra bir de ibrayı has ve ibrayı âm olmak üzere aynlın : yalnız bir hususa müteallik alacaktan (meselâ beyi de semenden, kirada icar bedelinden ibraî, vaz geçmek böyledir. İbrayı âmda ise alacaklı borçlı nezdindeki, menbaı ne olursa olsun, her alacaktan borçluyu ibra eyler. İbrayı âm makabline şâmil olur, mâbâdine şâtmil olmaz; yani ibbra senedi senet tarihinden evivel doğan borçlann hepsine şâmil olur; senet tarihinden sonraki alacaklarla alâkası yoktur. Bu teorik bakımından da doğıuduur; zira henüz doğmamıs alacaklar ibra mevzuu olamaz. Bundan şu netice de doğar : İbra senedinde alacaklı ile borçlu arasında senet tarihinden sonra doğacak olan borçlann da sâkit olacağı mukayyet olsa, bu kaydun nazara alınmaması icap eder. Alacaklının ibrayı âm senedi tarihini müteakip borçlu nezdinde tahakkuk edecek olan alacaklannın bunlann doğumunu müteakip ibra muamelesine aynca tâbi tutulmalan icap eder. Yoksa mukaddem senetdeki kaydın muahhar borçlann sükutunu teminen dermeyanı münasip olmaz.

Bi) Borç mevzuunun sonradan imkânsız hale gelmesi ve empré vesion (clausula $R$. Sic Stantibus) kaidesi.

a) Borç mevzuunun sonradan imkânsız hale gelmesi.

1) Meselenin vaz'ı :

Bir akit mevzuda imkânsızlı varsa bâtıldır, keenlemyekûndur, yoktur, yapılmamıs hükmündedir. Binnetice öyle bir halde akit mevzuunun sonradan imkân dahiline girmesi ve bâtıl akdin sıhat iktisabı dá mevzuu bahis değildir.

117 nci ve müteakip maddelerde hülkme bağlanan imkânsızlık, akit yapıldığı anda mümkün olan mevzuun bilâhare, yani, akdin inikadı ânından sonra imkânsız hale inkilâbı keytiyetidir. Bir iki misal zâit olmaz: A, B ye evini kiralıyor, ev ertesi gün zelzele felâketi ile yłkulyyor. İşte burada akit yapıldığı zamanda ev vardı. Fakat ertesi gün yok olduğundan A nin mecuru B emrine âmâde tutmak borcu sakıt olur. A, B nin portresini yapmayı taahhüt etse, mukaveleden sonra işe başlamadan veya yanya gelmişken bir kazasında kollarını, veya gözlerini gaip etse, akdin icrası sonradan imkânsız hale gelir.

Borç mevzuunun sonradan imkânsız hale gelmeși ile emprevizion (clausula Rebus sic stantibus) kaidesinin mucip olduğu hali yekdiğe- 
rinden ayırmak lâzmmdır. Illerde de görüleceği gibi bu halde borcun mevzuu imkânsız hale gelmez, ancak akit yapıldığı andaki serait fevkal'ade değişerek borçlu ifaya zorlanırsa vaziyeti himayeye muhtaç şekilde ağırlaşır. Mevzu tedarik olunabilir, binnetice ifada imkânsızlı mevzuu bahis değildir ${ }^{40}$.

2) İmkânsızlığın çeşitleri :

İmkânsızlık ikidir : küllì ve kısmî. Birincisinde akit henüz icra edilmeden evvel imkânsızlık vâki olur; ikincisinde ise, bir borcun bir kısmı ifa edildikten sonra hâdis olur. A, B ye 100 ton emtia teslimini borçlu olsa, 80 tonunu teslim ettikten sonra, 20 tonunu bulmak gayn mümkün hale girse, akdin icrası 20 tonluk için gayn mümkün hale gelir. A, B ye 100 tonluk semeni peşin vermiş idi ise, 20 tonluğa tekabül edeni vücudu nihayete exmiş sebeble vâki haksız iktisaba istinaden istirdada haklı olur. A, B ye 1000 ton türk buğdayı satsa, henüz hiç bir teslim vâki olmadan Devlet bir kanunla âmme menfaatine bütün buğdaylan istimval veya iştira etse, borç sonradan külliyen imkânsızlık sebebiyle sakıt olur.

Kısmî imkânsızlık borçluya bütün borcun sukutunu dermeyand hak vermez ${ }^{41}$. Bir fabrika diğerine 1000 ton un taahhüt edip 500 tonunu tedarik ve teslim maksadiyle emre âmade tutsa tesellüm vâki olmadan, memlekette ve hariçte artik buğday tedarikine imkân kalmasa, müteahhit, bunu bahane ederek tesellüme âmade olan 500 ton buğdayın teslimin: red edemeyeceği gibi, kıtlık hâsıl olduğundan dolayı semeni tezyit suretiyle teslimi de dermeyan edemez.

3) Borç mevzuunun imkânsız hale gelmesiyle sukuutun şartlanı :

117 nci maddnin 1 nci fikrası borç mevzuunun sonradan imkânsız hale gelmesi ile borcun sukutu şartına şöyle işaret ediyor : Borçluya isnat olunamayan haller münasebetiyle borcun ifası mümkün olmazsa, borç sakıt olur'".

Görülüyor ki esaslı tek şart ifada imkânsızlığın borçlunun kusurundan neş'et etmełmiş olmasıdır. A, B ye evini icar etse, B henüz intifaa başlamadan veya başladiktan sonra $A$, evini kasten yaksa, veya esash tamirati yapmadığından dolayı ev gayn kabili intifa hale girse,

40) Teferruat ve sair farklar için C.R.S.St. kaidesine ait bahse bakınız.

41) T.M. Ticaret Dairesinin 7-4-1946 gün ve 191/916 sayılı kararı da bu- 
borç ifada imkânsızlık dolayısiyle sakıt olmaz. Zira imkânsızlık birinci halde borçlunun en ağır kusuru (kasıt) ikinci halde ihmal veya tedbirsizlik $^{42}$ dolayısiyle borçluya isnat edilebilen hallerden dolayı hâdis olmuștur.

Nazik cihet şudur : İfanın sonradan imkânsız hale gelmesi akdin infisahın tevlit etmez; ancak, imkânsızlık taallûk ettiği borcu sakıt eder. Aksi olsa idi kısmî imkânsızlık bütün borca sâri olurdu, yani vaktiyle imkân dahilinde olup da vâki ifa ile elde edilen menâfi vücudu nihayete ermiş sebebler haksız iktisap kaidesince iadeye tâbi tutulurdu. Bir misal verelim : A, 'B' ye 100 ton buğdaydan 80 tonunu teslim etmiş, 20 sinin teslimi imkânsız hale gelmiş olsa, B nin 80 tonu iade eylemesi icap ederdi. Halbuki 80 ton ifa bakımından hakkı mükteseptir. İşte imkânsızlığın mâbadine şumulü kardesinden anlaşılacak şey bu izah edilen husustur.

4) İki tarafa vecibe tahmil eden akitlerde imkânsızlığın hükmünï 117 nci maddenin 2 nci fikrası şöyle ifade ediyır : "Karşılıklı taahhiütleri hâvi akitlerde bu suretle berî olan borçlu haksız iktisaplara müteallik hükümlere tevfikan almış olduğu şeyleri iadeye mecbur ve kendisine henüz tediye edilmemiş bulunan şey'i istemek hakkımdan mahrum olur".

Beri olan borçlu diğem tarafa peşin bir menfaat temin etmiş veya bir şey vermemişse, diğer taraftan onu alır. Bir tarafa vecibe tahmil eden akitlerde, borçlu borçtan kurtulur. Hattâ diğer tarafin ifa ile ilgili normal masraflannı da ödemekle mükellef olmaz.

İki tarafa vecibe tahmil eden akitlere dair kaydedilen kaidenin istısnası 117 nci maddenin 2 nci bendinin son ibaresinde mezkûrdur. "kanun veya akitle borcun ifasından evvel dahi vukua gelen zarann alacaklıya tahmil edilmiş olduğuu haller bundan müstesnadır."

Beyide ne-fi hasara dair olan kaide bu hallerden birine tipik bir misaldir : Mebi akdin inikadından ve fakat tesellümden evvel hasara uğrasa, ifa imkânsız hale ge'mis olsa bile, bu imkânsızlı yalnız satıcı lehinedir; yani 117 nci maddenin 1 nci fikrasındaki kaide tatbik olunarak satıcı ifanın hasar dolaysiyle imkânsız hale gelmesi hesabiyle, müşteriden vaktiyle almış olduğu semeni iadeye mechur olmadığı gibi,

42) 117 nci madde imkânsızlığın borçluya isnat edilebilen hallerden ileri gelmiş olmasi halinden bahsedip bu hallerin borçlunun ağır kusuruna münhasır olması sartından bahsetmiyor. Şu halde ağır ve hafif her türlü kusurdan imkânsızlığın doğmuş olması kâfidir. 
kısmen almış ise, mütebaki semen üzerindeki hakkı da sakıt olmaz ${ }^{43}$. Zira bütün bu hususat kanunla kabul edilmiş, ve binnetice $117 / 2$ deki kaidenin tatbikine mahal kalmamıştır.

b) Clausula R.S. Stantubus kaidesi (İmprévision nazariyesi).

Ahval ve şeraitin sonradan çok ağır bir şekilde değişmesi ahde vefa "Pacta sunda servanda" prensibine tek istisnayı teşkil eder. Ahval ve şeraitin borçlu aleyhine olarak sonradan değişmesi ile ifanın sonradan imkânsız hale gelmesi arasındaki farka işaretten sonra meseleyle alâkalı kaideleri icmale çalışacağız.

İfanın imkânsız hale gelmesinde akit ya mevzuda sonradan imkâr:sızlık veya borçlunun ifa kabiliyetini zâyi etmesi dolayısiyle gayıı kabili icra hale gelir. Ahval ve şeratin sonradan çok ağır şekilde dahi olsa değişmesinde akit icra edilebilmek hassasını muhafaza eder. Meselâ mevzu mütmkündür, fakat tedarik borçlunun malî vaziyetini pek ziyade ağırlaştırrr. İşte bu vaziyette kanun evvelâ borçluyu himaye maksadiyle borcun ifası külfetini bertaraf eder.

Ahde vefa prensibi pek mühim olup ${ }^{44}$, ihlâli eşhas arasındaki normal münasebeti bozar, efradı yekdiğerine itimatsızlık yüzünden muameleye girișmeye dahi sevketmekten men eder. Bunun için gerek beyneddüvel hukukta, gerek borçlar hukukunda, ve hattâ ahlâki ve içtimaî münasebatda ahde vefa kaidesinin ihlâli ve istisnaya uğraması pek sıkı kaidelere rapt edilmiştir. Borçlar hukukunda dahi ahval ve şeraitin sonradan değiß̧mesi halinde mukaveleden xücu çok ciddî ve ağır şartlara bağ. lanmıştır ki şunlardır :

1) Borçlunun ve hattâ iki tarafın ahvalin sonradan değişeceğini bilmemiş olması icap eder. Borçlu borç altına girerken buna vâkıf ise istisnadan müstefit o'maz. Meselâ kömürün kilosu akit yapılırken $10 \mathrm{ku}$ uş iken borçlu bunun borcun ifasr sıralarında 40 kuruşa çıacağını bilse, ve ifa zamanında kömürün kilosu bu miktara baliğ olsa eda ile mükelleftir. Blorçunun keyfiyeti bildiğini ispat alacaklıya düşer. İspat için şekil ycktur. Her türlü beyyinat makbuldur. Alacakl borçlunun bu hususta sebketmiş bir sözünü dahi ispat için kullanabilir.

43) Esasen mebide hasar ifanın imkânsız hale gelmesine de mutlaka vesile olmaz. Kurılan saatin aynı tedarik edilebilir.

44) Akdî münasebatta "cezaî șart", "zamanı rücu" gibi hususî müeyyidatın kabulü dahi hep ahde vefa kaidesinin muhtel olmamasinı akden temin eyleyen tedbirlerden, pesin çarelerden ibarettir. 
Ahval ve şeraitin sonradan değişeceğini alacakl bilmiş, akit yapilırken borçludan keyfiyeti hile ile gizlemiş ise, bu takdirde borçlunun bunu ispat etmesi șartiyle hile sebebiyle akdin feshini istemeğe bizce hakkı olmak lâzımdır.

2) Her ne bahasına olursa olsun borçlunun ifayı taahhüt etmemiş olması lâzımdir. Etmiş ise mesele yoktur. Yani taahhüt edilen emteanın kıymeti kendisini pek fazla izrar etse bile akitten rücua hakkı olmaz. Borçlunun ifayı her ne bahasına olursa olsun kabulü bâtıl addedilemez. Zira ahde vefaya istisna teşkil eden bu keyfiyet âmme intizamından değildir. Diğer cihetten herkes mamelekî tasarrufta serbesttir. Kaldı ki ka. nunda keyfiyetin âmme intizamından olduğunu nâtık sarih veya zımnî birı işaret dahi yoktur.

3) Ahval ve şeraitin değişmesiyle borçlu mukaveleden rücu edemez.

Mukavele revizyona tâbi olur, Hâkim gerek borçlunun gerek alacaklının menfaatine mutabık şekilde tâdilât icra ederek gözden geçirilmiş ve tâdil edilmiş olan mukavelenin icrasını emr eder. Bu, ahval ve şeraitin evvelden bilinmeyen esbab dolayısiyle değişmesi ile ifanın sonradan imkânsız hale gelmesi arasındaki farkm tatbikatından ibarettir.

Görülüyor ki emprevision nazariyesi ahde vefa prensibinin basit bir şekilde ihlâlini sağlayacak mahiyetde değildir.

C) Mürurzaman Md. (125)

a) 1. Giriş ve sukut haklar farki. 2. Mürur zamanın sebebi ihdası, kat'iyeti. 3. Mürur zaman müddetleri. A. Müddetlerin nevileri. B. müddetlerin kat'iyeti. 4. Mürur zamanın kat'ı ve tatili. A - Kat'ı B - Tatili. 5. Mürur zamandan feragat. 6. Mürur zamanin hükmü.

a) Giriş ve mürur zamanın sukutu haktan farkı.

1) Giriş :

Diğer sukut sebeblexi hilâfina olarak, mürur zaman hakkı kaldırmaz. Ancak alacağın mutalebe edilebilmek, borçlunun nzası hilâfina Devlet zoru ile tahsil olunabilmek vasfinı izale eder. Bunun içindir ki mürur zaman vâki olmasına rağmen borçlu kabul ederse ${ }^{45}$ eda aynen mutalebe vasfını haiz normal bir alacağın edası imiş gibi istirdada mahal vermez. Yine ayni sebebe mebnidir ki hâkim mürur zamanı resen nazara alamaz. Ve borçluya mürur zamanla ilgili bir ikaz da dahi bu-

45) Mürur zamandan feragat bahsine bakınız. 
lunamayacağı gibi bunu hatırlatıc bir lâtız dahi kullanamaz ${ }^{46}$. Eğer mürur zaman alacağı̆ düşüren sair sukut sebebleri gibi olsa idi bütün bu neticeler hâsıl olmazd. Takas, tecdit, imkânsızlk gibi sair borcun sukut esbabı tahakkuk edince hâkim açılan alacak davasını red eder. Halbuki mürur zamanın vukuuna vâkıf olan hâkim alacak davasını kendiliğinden reddedemez. "Mürur zamanın 'hükmü bahsinde de görüleceği üzere borçlu mürur zaman definde bulunursa ${ }^{47}$ davanın red cihetine gidilebilir, aksi halde alacak 25 senelik bir alacak olsa dahi alacağın tahsiline hükmetmeğe mecburdur ${ }^{4}$. Şundan anlaşlıyor ki, mürur zamandan gayıı sukut esbabi alacağı ve binnetice dava hakkın ${ }^{49}$ kaldırr. Mürur zamanda hak sakıt olmadığından ${ }^{50}$ dava hakkı da sakıt olmaz; olsa idi mürur zamana vâkıf olan hâkim o andan itibaren davayı redde selâhiyetli olurdu.

2) Mürur zamanın sebebi ihdası :

Bir sistem halinde bulunan her eski ${ }^{51}$ ve yeni hukuk sisteminde mürur zaman müessesesi kabul edilmiştir. Hemen kaydedelim ki hiç bir alacak üzerinden uzun zaman geçmekle sakıt olmaya sâlih ve mütehammil değildir. Alacaklı ahlâk ve din telâkkilerince ve borçlusunu ebediyen, mutekit halk arasındaki tâbir ile "öte dünyada" dahi yakasna sarlabilecek bir hakka sahiptir. Filhakika öyledir. Bu ahlâki ve dinî kaidelerin tesirinden olacaktır, ki, mürur zaman müessesesini kabul eden en modern muasır' Borçlar kanunlan dahi üzerinden muayyen bir zaman geçmiş olan alacaklan tamamen iskat etmemiş, tabî̀ borç olarak devamını hükme bağlamış ve hattâ bu borcu pasif bir şekilde kanunen müeyyideleyerek himaye etmiştir. Filhakika, ilerde de görüleceği üzere müruru zamana uğramıs olan bir alacağı borçlu alacaklyya isteyerek 52, yani ahlâki mülâhaza galip gelerek, eda etse bir daha istirdat edemez. Yani mürur zamana tâbi idi diye dava ikame edip iadesıni talep edemez.

46) Aksi halde taraflardan birine (borçluya) yol göstermiş addolunarak redde müstahak olur.

47) Mürur zamanın hükmü bahsine bakınız.

48) Bu esbap dava hakını kaldırmasa idi hâkim bu esbabın subutu anından itibaren davayı red selâhiyetine sahip olamazdı.

49) "Tabiî borçlar" bahsine bakınız.

50) Roma ve islâm hukukunda da böyledir.

51) Şakir Berki, Borçlar hukuku, Ankara, 1956, s: (331)

52) Trade ile eda şarttır. A, nın B ye 100 lira borcu mürur zamana uğramış olsa $B$, A ile konuşurken şu yüz lirayı ver bir bakayım diye alsa, veya çalsa sonra 100 lira borcuna say dese, B 100 lirayı iadeye mecbur olur. 
Alacağ̀n kanunî müddet zarfında talep edilmemesi alacaklının ya tahsil ettiği veya tahsil etmek istemediğini farz ettireceğinden, bu müddetin hulûlüinden sonra mahkemeleri işgâli câiz görülmemiş ve bu suretle adalet teşkilâtının eski ve kesir davalarla mahlul bulunmasına engel olunmak istenmiştir : Zikredilen farz ve karine mutlak olup hilâfının ispatı kabui olunamaz. Mürur zamanın ihdasına daha bazı esbab da zikredilebilir. Uzun zamandan beri takip edilmemiş alacağın ispat kabiliyetini gaip etmesi bu delillerden biri olarak zikredilmekte ise de, bir alacağın uzun senelere rağmen delilden mahrum olmayacağı da tatbikatta görülen vâ. kıalardandır ${ }^{53}$.

3) Mürur zamanın sukutu haktan farkı :

$1^{\circ}$ ) Umumiyetle üç nevi müddet varidrr: Mürur zaman müddeti, sukutu hak müddeti ne mürur zaman ne de sukutu hak müddetinden olmayan müddetler 54 . Burada yalnız sukutu hak müddeti ile mürur zaman müddeti arasında tatbikatda da büyük ehemmiyeti olan teknik fark. lan işaretle iktifa edeceğiz.

Mürur zaman âmme intizamından değildir. Sukûtu hak âmme intizamındandır. Bu kaidenin neticeleri şunlardır :

aa) Taraflar sukutu hak müddetini uzatp kısaltamazlar ve bu müddetten feragatleri dahi câiz değildir. Mürưr zamanın uzaltılıp kısaltılmasma ve sonradan olsa dahi feragate cevaz vardır. Bu cihetleri mahsus bahis!erinde göreceğiz.

bb) Sukutu hak müddeti kendiliğinden (re'sen) nazara alınır. Mürur zaman müddeti hakkında bu mümkün değildir. Meselâ Devlet Ŝurasına açılacak davalar 3 ay içinde ikame olunmalıdır. Aksi halde şûra davayi red eder. Zira bu müddet sukutu hak müddetindendir ${ }_{55}$.

cc) Sukutu hak müddeti kat ve tatil sebebleriyle alâkalı değildir. Halbuki mürur zamanı kat ve tatil eden esbab mevcuttur, ki bu esbabla

53) Meselâ bir alacağı teyid eden senet mirascıdan mirascıya intikal edebilir. Fakat buna rağmen 10 sene hulul etmis ise, alacağın tahsiline mevzu hukukumuz yine müsait değildir.

54) Alacağın muacceliyet müddetleri gibi müddetler böyledir.

$5_{5}$ ) Metinde de görüleceği üzere, usul iflâs kanunlariyle sair kanunların vergi ve sair gibi âmme kanunlarındaki müddetlerin ekserisi sukutu hak müddetidir. 
mürur zaman müddetleri hukuken veya fiilen uzamış olur ${ }^{56}$. Sukutu hak müddetinin hakiki manasiyle âmme intizamından bulunması bu müddetin bu sebeblerle uzamasına da mânidir. Ancak sukutu hak müddet: esbabı mücbire ile uzayabilir. Şu kadar ki bunun için kanunda sarahat lâzımdır.

Bir müddetin sukutu hak müddeti olabilmesi için hakkın mutlaka - müddet zarfinda kullanılması aksi halde sakıt olacağı mevzuu bahis bu!unmalıdır. Meselâ mahkemelerin verdikleri ilk mehiller ekseriya susukutu hak müddeti değildir. Kat'i mehil sukutu hak müddetidir.

Birinci mehilin mürurundan sonra artık aynı hakkın istimâli için ikinci bir mehil verilmesi imkânı olmasa idi birinci mehil sukutu hak müddetinden olurdu. Usul kanununda yalnız bir defaya mahsus olmak üzere verileceği musarrah mehiller sukutu hak müddetindendir.

dd) Mürur zaman nevileri :

Hukuk iki nevi mürur zaman kabul eder : İktisabî mürur zaman, iskatî mürur zaman. Bu sonuncusu Borçlar Hukukunu alâkadar eder, bir alacağın mutalebe edilebilmek hassasının zevaline sebeb olur. İktisabî mürur zaman ise aynî haklarda, gayn menkul ve menkul mülkiyetinin elde edilmesine vısile olur. Her iki mürur zaman arasındaki bâriz fark şudur: lktisabî mürur zamanla bir şahıs menkul veya gayn menkul bir mala sahip olur. O mal üzerinde asıl sahibin hakkı tam manasiyle sakıt olur. Halbuki iskatî mürur zamanla alacak tamamen sâkıt olmaz, tabiî bir alacak olarak devam eder. Şu farkın tatbikî mühim neticesi şudur : A, B nin menkul veya gayn menkulünü iktisabî mürur zamanla iktisap et. se, bilâhare B ye şey'i terk etse hibe maksad ile temlik ispat edilmezse bey'e karine olabilir, veya istirdadı câiz olur. B, vaktiyle bu şey kendisine ait olduğunu ve $A$ nın da kendisine iade ettiğini iddia ederek şey'i aadeden müstağni olamaz. Halbuki iskatî mürur zamanda keyfiyet aksinedir; mürur zamana rağmen borçlu alacaklıya öderse alacaklı tediye edilen meblâğı iade etmez. İki mürur zaman arasındaki bu fark iktisabî mürur zamanın ilk malikin şey üzerindeki hakkmı tamamen düşürmesine mukabil, iskatî mürur zamanın alacağı tabiî borç olarak devam ettirmesinden doğmaktadır.

Aynî hak tesis eden mürur zamana dair kısa bir bilgi verdikten son-

56) Mürurzamanı tâtil eden sebeplerle kat eden sebepler bu esbabdandir. 
ra, mevcut Błorçlar Kanununun iskatî mürur zamana mütedair olan esas ve ahkâmını tetkike devam edeceğiz.

Aynî hak tesis eden mürur zaman gayn menkul ve menkullerde ayn ayn nazara alınmıştır; gayn menkullerde iktisabî mürur zaman $\mathrm{M}$; Kanunun 638 ve 639 ncu maddeleri bâhistir. 638 nci maddesi âdî iktisabî mürur zamana 639 ncu madde ise, Fevkal'âde iktisabî mürur zamana aittir. Âdi mürur zaman 10, diğeri 20 senelik müddete tâbidir. Âdi mürur zamanla iktisap için iktisap edecek olanda hüsnüniyet bulunmak lâzımdir ${ }^{57}$.

Fevkal'âde iktisabî mürur zamanda müddet 20 senedir. Bunda hüssnüniyete lüzum yoktur"58 639 ncu madde şöyledir : "Tapu sicilinda mukayyet bulunmayan bir gayn menkulü nizasız ve fâsılasız 20 senc müddetle ve mâlik sıfatiyle yedinde bulundurmuş olan kimse o gayrı menkulün kendi mülkü olmak üzere tescili talebinde bulunabilir...." 639 ncu maddenin 2 nci fikrasında tapu sicilinde mukayyet olup da maliki anlaşlamıyan veya 20 sene evvel vefat eden yahut gaipliğine hükmedilmiş olan bir kimseye ait gayn menkulün de 639/1 deki şartlar dairesinde iktisap edilebileceğini yazmaktadır.

Fakat A nın tescil talebi B nin aynı gayn menkuldeki tasarrufu henüz 20 seneye baliğ olmadan vâki olsa tescilin A lehine yapılması icap eder. Zira, bu ihtimalde B nin henüz zilyetlik ve binnetice gayn menkulün uhdesine tescili talep hakkı doğmamıştır.

639 ncu maddedeki mürur zamanda hüsnüniyet aranmaz.

Menkuller hakkında iktisabî mürur zaman M. Kanununun 701, 902, 904 ncü maddeler sarihtir. Menkul mülkiyeti behemehal hüsnüni-

57) 638 nci madde : "Muhik bir sebeb yok iken tapu sicilinde uhdesine mâlik sıfatı ile mukayyed bulunan bir gayrımenkulü fâsılasız ve nizasız on sene müddetle ve hüsnüniyetle yedinde bulunduran kimsenin o gaymmenkul üzerindeki hakkına itiraz olunamaz." Hüsnüniyet muhik sebebe müstenit tescil mevcut değilken tescilin muhik sebebe istinaden yapllmış olduğunu bilmek hususundaki samimi zandir.

58) Her iki halde de nazik cihet sonraki zilyetliğin tescile esas olacağı keyfiyetidir. Keyfiyeti bir iki misal ile açılamak yerindedir : A, bir gayr menkulü 20 sene nizasiz ve fasılasız tasarruf etse, sonra $B$ ayni gayrı menkule 20 sene mutasarrıf olsa, B nin tescil talebi kabule sayandır. A, ayni gayrı menkulde daha evvel 20 sene 639 ncu madde şeraitine göre zilyetliğini ikmal etmiş bulunduğunu iddia etse mesmu olmaz. 
yet şartiyle iktisap olunur. Demek ki gayn menkullerin iktisabî mürur zaman ile menkullere ait iktısabî mürur zaman arasındaki fark bilhassa hüsnüniyet unsuurunda göze çarpar. 701 nci madde menkullere ait iktisabî mürur zamanı şöyle tanzim ediyor : "Başkasının menkul bir malını nizasız ve fasılasız mülkümdür diye ve hüsnüniyetle beş sene yedinde bulunduran kimse o mala mürur zaman sebebi ile malik olur..."

$\mathrm{Bu}$ hüküm muvacehesinde Borçlar Kanununda münhasıran borç münasebetine kabili tatbik olan iskatî mürur zamanın menkul mülkiyetinin iktisabında istimaline cevaz olamaz. İsterse bu menkul borç münasebetinde mevzuu bahis olsun hüküm aynıdır. Meselâ emanet akdinde ${ }^{59}$ emanet alan hiç bir veçhile emanete verilen şeyi iktisap edemez. Zira şey'e emanet aldığını bilmiş olduğundan dolayı hüsnüniyetle zilyed olmadığı gibi, şeyde emanet akdinin mahiyeti icabı tasarruf yetkisi de yoktur. Müstevda emanete verilen menkul üzerinde menkul müikiyetinin iktisabı şartlarından olan hüsnüniyet ve tasarruf yetkisine selâhiyetli olmadığından, bilâkis şey'in yedinde emanet olarak bulunduğunu bildiğinden suiniyetlidir. Menkul mülkiyetinin iktisabı ise, gayn menkuul mülkiyetinin iktisabı hilâfına olarak, daima hüsnüniyet unsur ve şartı ile mümkündür.

$\mathrm{Bu}$ sebeplerden dolayı bazı hukukçuların ${ }^{60}$ emanet mevzuunun 10 senelik mürur zamanın hululü ile müstevdanın mülkiyetine intikal edebileceğini natık fikirleri bizce kabule şâyan değildir. Bu nâzik ve tatbikî ehemmiyeti haiz mesele üzerinde biraz tevakkuf etmek ve bilhassa bu müelliflerin fikrine mesnet olan mütalâat üzerinde durmakda fayda vardır.

Aynı meseleyi Federal Mahkeme de tezekkür etmiş, müstevdanın 10 senelik mürur zamanın tekemmül etmiş olmasına rağmen emanet șey'e teme!lük etmeyeceğini belirten bir karara varmış ise de, $456 \mathrm{ncı}$ maddedeki "idada müddet tâyin edilmiş olsa bile mudi ida edilen şey'i her vakit geri alabilir" hükmüne istinat eṫmiş, mezkûr müellifler mahkemenin bu mucip sebeb:ni haklı olarak cürüttükten sonra 10 senenin hululü ile ida edilen şey'in mudi tarafından artık istirdat olunamayacağı neticesine varmışlardır. Hakikaten Federal Mahkemenin meselede sözü geçen hükme istinat etmesi münasib değildir. Zira idada tâyin edilen müddetin manası mezkûr maddede pek sarihtir: Müstevda bu müddet geçmeden

59) Emanet alan emanete verilen şey'in kendisine ait olmadığını bilir.

60) A. E. Arsebük, a. g. e, s: got - 902 
evvel ida mevzuunu daima muhafazaya mecburdur; onu zorla mudiye teslim edemez; mudi bu müddetten evvel vâki teslim talebini reddederse müstevda emanet mevzuunu yedi emine dahi terk edemez. Zira vakitsiz teslimi kabul etmeyen mudi mütemerrid alacakl durumunda değildir.

Emanet verenin müddet hulul etmeden evvel şey'i istediği zaman geri ıstemesi gayet tabiî olup emanet akdinin mahiyeti icabındandır da; zira emanet akdi müstevdaa kaideten şey'i kullanma hakkı vermez. Binaenaleyh, mudiin müddet tâyin edilmiş olan hallerde sşey’i müddet hululünden evvel dahi talep etmesi ve müstevdain bu talebi behemehal is'afi pek tabiî olup, kanuna yukarda mezkûr hükmün ilâvesine dahi mümanaat edici mahiyettedir. Su halde Federal Mahkemeyi tenkit eden müellifler netice itibariyle değil mahkemenin mucip sebebinin yanlışığı bakımından haklıdırlar. Bu müellifler Federal mahkemeyi tenkitten sonra tevdi edilen şey'in tâyin edilen müddetin hululünden itibaren değil, vediada hususî mürur zaman olmadığından, 125 nci maddedeki 10 senelik mürur zamanın tekemmülü tarihinden itibaren müstevdain mülküne intikal edebileceği yolunda bir kanaat izhar eylemektedirler. Bu kanaatde isabet bulunamayacağı, menkul eşyanın iktisabî mürur zamana dair olarak kaydetmiş olduğumuz mütalâat muvacehesinde bizce aşikârdır. Diğer cihetten 10 senelik umumî mürur zaman vediada şu hallerde nazara alınabilir.

i) Vedia ücretli idi ise bu ücretin talebinde

ii) Müiddet tâyin edilmemiş ve mudi de 10 sene içinde talep etmemiş ise, emanetcinin -şey'i yedi emine tevdii icab eder : mudi müddetsiz idalarda şey'i hiç talep etmezse, müstevda şey'i ilelebet muhafazaya mecbur değildir. 10 sene hułulü edince tevdi ile muhafaza külfєtinden kurtulabilir. 10 sene geçmeden mudi bizce tesellüme dahi zorlanamaz ${ }^{61}$.

61) Kaydedilen bu sebeplerden dolayı emanet ve âriyete verilen menkul eşya müstevda ve âriyet alan nezdinde 10 seneyi mütecaviz kalmış olsa bile bunların mülkiyetine dahil olmaz. Zira her iki akitde de şey yedinde bulunan kimseler hüsnüniyetli değildir. Menkul mülkiyetinin iktisabında hüsnüniyet asıldır. A, B ye bir otomobili emanet veya âriyet olarak verse 10 seneyi mütecaviz bir zaman talep etmese otomobil $B$ nin olmaz. A nin talep hakkı sâkıt olmaz. Bu, aynî hakların şahsî haklara nazaran dâimi vasfından doğan pek tabî̀ bir neticedir. 
Vediada 10 senelik umumî iskatî mürur zaman vedia akdind'en doğan ve emanet şey'in mülkiyeti ile alâkalı bulunmayan şahsî hak ve mükellefiyet için mevzuubahis olabilir.

Şu izahattan iktisabî mürur zamanla iskatî mürưr zaman arasında ikinci zâhir olur: İktisabî mürur zamanda hüsnüniyet (638) ve mâlik sifatiyle tasarruf (638 - 639) şartlan ehemmiyetli iken iska'î mürur zamanda bu şartlar nazara alınmaz. Blinnetice borçlu alacağı suiniyetle mürur zamana uğrattmış olsa dahi alacaklı suiniyett def'inde bulunamaz, hakkı sakıt olur. Meselâ alacaklı mürur zamana uğramasına iki ay kalmış olan alacağını borçludan istese, borçlu iki ay değil daha üç aydan istifade edeceğinden bilhesap bahis ve ikna ederek alacaklıyı üc ay sonra talebe razı etse, alacak yine mürur zamanla sakıt olur. Borçlu alacaklıyı "borç mürur zamana uğrasa bile borcunu ödeyeceğim gibi...." şifahî veya tahrixî vaatlerle ikna etse hüküm yine aynıdır.

Zira henüz tekemmül etmemiş mürur zamandan feragat ${ }^{62}$ veya bu yolda yeni bir senet tanzimi haizi ehemmiyet değildir ${ }^{63}$.

ee) Mürur zamana uğramayan alacakları :

Kanunda hangi alacakların mürur zamana tâbi olduğu, hangilerinin olmadığı meselesi yazılı değildir. 125 nci maddedeki ".. her dava on sentlik mürur zamana tâbidir” ibaresinden de her alacağın mutlaka mürur zamana tâbi olduğu istidlâl edilemez. Zira ibare mürur zamana tâbi olup da hakkında hususî bir mürur zaman mevcut olmayan alacaklann umumî iskatî mürur zamana tâbi bulunduğunu beyan için sevk olunmuştur ${ }^{64}$.

Prensip itibariyle her alacak mürur zamanla sâkıt olur. Bu umumî kaidenin istisnası kanunlann ekseriya sarih ahkâmı ile tezahür eder. Gerek âmme, gerek hususî hukuka ait kanunlar bir alacağın mürur zama-

62) Mürur zamandan feragat bahsine bakını.

63) Ancak ilerde de görüleceği üzere senede merbut olmayan bir alacağın sonradan senede bağlanması o alacağı 10 senelik mürur zamana tâhi kllar. Md: 135/2 Binnetice borçlu 5 senelik mürur zamana tâbi bir alacaik için mürur zaman vukuuna bir ay kala sened verse alacaklı 10 senelik mürur zamandan istifade eder; ve bu 10 senelik müddet seneđin tanzimi (yani ikrarin vukuu) anından başlar.

64 Kanunun lâfız veya ruhundan mürur zamana tâbi olmadığı anlaşlan alacaklar bu hükümle münasebettar değildir. 
na tâbi olmadı̆ğın tasrih ederlerse o alacak mürur zamana tâbi olmaz, 125 nci madde dahi tatbik olunamaz.

Ferdin devlete, Devletin ferde olan borçlan dahi mürun zamana uğrar. Borç âmme hukukundan doğsa bile hal aynindır. Vergi borçları da mürur zamanla sakıt olur. Âmme kanunlarında hususî mürur zaman mevcut değilse, âmme alacakları dahi 125 nci maddedeki umumî mürur zamana tâbi olur.

Alacağı̣n menkul rehni ile veya kefaletle temin edilmiş olması o alacağın mürur zamana uğramasına mâni olmaz. 138 nci madde menkul rehni ile temin edilmiş olan alacağın mürur zamanı ile alâkalı olarak şu hükmü ihtiva ediyor : "Alacağn bir menkul rehni ile temin edilmiş bulunması bu alacak hakkında mürur zaman cereyanına mâni olmaz ${ }^{65}$. Fakat alacakh rehinden istifayı hak etmek selâhiyetini muhafaza eder".

Görülüyor ki, rehinli bir alacak 10 sene talep edilmese dahi borçlu alacağın sukutunu dermêyan ile onun fer'i olan rehnin de iadesi lâzım geldiğini iddia edemez. Alaiakh rehni satar aladağmı istifa eder. Merhun tam alacağa tekabül eden bir meblâğ getirirse mesele yoktur. Daha az meblâğ temin etmişse merhunla temin edilmemiş olan kısım mürur zamanla sakıt olur. Burada şu nâzik cihete de işaret etmek icap eder: Rehinle müemmen alacak rehnin getirdiği meblâğ ile ıtfa edilir ise de, alacağın bütünü yıne mürur zamanla sakıt olmuş hükmündedir. Böyle olmasa idi alacaklı rehnin temin etmiş olduğu meblâğın (alacağa tekabül eden para) faizini de isteyebilirdi kì, buna imkân yoktur.

'Alacağın gayrı menkul rehni ile temin edilmiş bulunması alacak hakkında mürur zamanı kaldırır. M.K. 779 ncu maddesi şöyledir : "Gayn menkul bir rehnin tescili alacak hakkında mürur zamanın cereyanına mâni olư'".

Mürur zaman yalnız akdì borçlar da mevzuu bahis olmayıp, kanundan doğan her nevi borç mürur zamana tâbidir. Haksız fiillerden doğan tazminat borcu, haksız iktisaptan doğan iade borcu ilh. hep mürur zamana tâbidir.

Mürur zaman yalnız Borçlar kanunundaki alacaklara da münhasır

65) Rehin alacağın doğumu anında veya bilâhare tesis edilmiş olsun hüküm aynıdır. 
bir müessese değildir. Aile, miras, aynî haklardaki alacaklar da mürur zamana tâbidir.

ff) İskatî mürur zaman müddetleri :

Bu bahiste alacak mürur zamanında müddetlerin nevileri ile mebde ve hesabindan bahsolunacaktır.

4) Mürur zaman müddetleri :

Iskatî mürur zaman müddetleri üç nevidir : 10 senelik, 5 senelik daha az veya daha çok müddetli mürur zamanlar.

$\left.1^{\circ}\right) 10$ senelik mürur zamana umumî üçüncülere hususî mürur zaman demekte hatâ olmaz. Her bir halin ayn ayn incelenmesi lâzımdır:

10 senelik mürur zamana tâbi alacaklar :

125 nci madde bu hususta umumî kaideyi şöyle vazeder: "İşbu kanunda başka suretle hüküm mevcut olmadığı takdirde her dava 10 senelik mürur zamana tâbidir."

Madde şöyle izah edillmek lâzımdır ,: Kanunlarda bir alacak hakkında mürur zamandan bahis yoksa Borçlar kanununun 10 senelik mürur zamanı tatbik olunur. Alacak âmme kanunlarından doğmuş olsa bile kanunda mürur zaman hakkındaki sükût teșriî bir kararla izale edilmedikçe Borçlar Kanununun 10 senelik umumî müruru zamanı. nazara alınmak lâzımdır.

Kanunlarda bir alacak hakkında mürur zaman tâyin edilmiş ise م mürur zaman tatbik olunur.

Hususî müruru zaman müddetinin kısa veya uzun olması haizi ehemmiyet değildir. Müddet uzun olsa, meselâ $\mathbf{4 0}$ sene bulunsa bile, 40 sene nazara alınır. Mürur zamanın hususiyeti de bu noktada kendisini gösterir.

Bazı hallerde kanun hem hususî hem umumî mürur zamanı nazara alabilir. Meselâ haksız fiillerle, sebebsiz iktisaptaki iade borcunda keyfiyet böyledir. Bu bahislerde kanun hem bir senelik, hem on senelik mürur zamanı nazarı itibare alıyor. Dikkati câlip cihet şudur : 10 sen əlik mürur zaman haddi içinde bir senelik mürur zaman hulûl ederse artık 10 senelik mürur zamandan istifade edilmez. Meselâ haksız fiillerde mağdur hem zarara, hem failine aynı zamanda muttali olmuş ise, artık geri kalan 9 senelik müddetten istifade edemez 10 se- 
nenin bitimine bir ay kala muttali olmuş ise, artık bir senelik hususî mürur zamandan istifade edemez; davanın bir ay içinde ikamesi lấzımdır. Isste burada umumî mürur zamanın hâkimiyeti bârizdir.

$\left.2^{\circ}\right)$ Beş senelik mürur zaman :

126 ncı madde beş senelik mürur zamana tâbi olan alacaklan sayiyor. Bu alacaklar, alelumum kiralar ${ }^{67}$; resülmâl faizleri; erzak bedeli, nafaka; otel ve lokanta masraflarından doğan alacaklar; doktor ve sair san'at erbabının ve avukatlann meslekî hizmet ve vezaifinden doğan alacaklar, maiyetde çalışan kimselerle müstahdem ve hizmetçilerin alacaklan amele ve bilcümle yevmiyecilerin alacklan.

Bilinecek cihet, bu sayılan alacaklann mezkûr kimselerin gördükleri işten doğan alacaklanndan ibaret olduğudur. Binaenaleyh, bir avukatın müvekkilden veya hizmetçinin efendiden karzen aldığı para borcu 10 senelik mürur zamana tâbi olur.

$3^{\circ}$ ) Hususî mürưr zaman müddetleri :

10 ve 5 senelik mürur zaman haricinde kalan ve müddeti daha az veya 10 seneden de uzun olabilen her türlü müruru zamana hususî mürur zaman denir. Kisa müddetli mürur zaman müddetleri 6 ay hattâ daha aşağı olabilir. Bazan husưsî mürur zamandan dahi fazla olabilir. Haksız fiillerde 60 ncı maddenin 2 nci fikrasındaki hüküm bunun delilidir. Cezayı mucip fiilden neş'et eden tazminat talebi ceza kanununda o fiil için tanınmıs folan daha uzun mürur zaman müddeti 30 sene olsa haksız fiild'en neş'et eden tazminat davası 30 senenin hululüne kadar açlabilir. Mağdurun zarar ve fâiline itțlaı 30 senenin bitimine bir seneden az bir müddet kala ve meselâ 2 ay kala vâkỉ olsa dava bư iki ay içinde ikame olunmak lâzımdır.

Âmme veya hususî hukuk kanunlannda hususî bir mürur zamana tâbi tutulmuş olan alacaklar Borçlar kanununun 126 ncı maddesindeki 5 senelik mürur zamana tâbi alacak nev'inden olsalar bile artık onlar hakkında Borçlar kanununun bu maddesindeki mürur zaman uygulanmaz; zira bu halde hususî kanun tatbik edilir68.

67) Yani menkul, gayrı menkul kiraları.

68) 127 nci madde işbu üçüncü babta tâyin edilen mürur zaman müddetlerinin tâdil edilmemesini ancak mukavele ile tâdil imkânsızlığına inhisar ettirmiştir. Hususî kanun ahkâmı umumî kanun ahkâmına mugayir olsa dahi tatbik olunacağı malûm bir kaidedir, Yeter ki hususî kanun tarihi umu- 
5) Mürur zamanın başlanbıcı ve mürurzaman müddetlerinin hesabi :

$\left.1^{\circ}\right)$ Mürur zamanı başlangıcı : Md: 128.

Mürur zaman alacağın mutalebe edilebilmek vasfını ref ettiğine göre, alacağın doğumu anı değil muacceliyet anı nazara alınmak iclap eder. Binnetice alacak iki sene evvel doğsa borçlu iki sene ecelden istiflade etse, borç iki sene sonundan itibaren mürur zamana tâbi olur.

Alacak doğumu ile muaccel olsa mürurzaman alacağa vücut veren hukukî muamelenin tekemmülü anından itibaren hesab olunur.

Muacceliyet ihbara vabeste olan hallerde de borç hakkında mürur zaman ihban müteakip cereyana başlar. İhbarlı muacceliyetde muacceliyet için ihboardan sonra müddet tâyin edilmişse, borç ancak bu müddetin hululünde mulaccel olacağından, mürur zaman da bu müddetin hululü tarihinden işlemeye başlar.

Talikî şarta bağhı borçlarda şartın tahakkukundan evvel mürur zaman mevzuu bahis olmaz. Zira şart tahakkuk etmeldikçe mutalebe kabiliyetini haiz bir borç yoktur; binnetice, mürur zaman da düșünülmez. Sart tahakkuk etmekle borç doğar. Şartın tahakkuk anı ile muacceliyet anı bir ise ona göre hükmedilir; değilse, yukardaki ihtimaller na. zara alınır.

Buraya kadar kaydedilen esaslardan muacceliyet ve ihbarl muacceliyete taallûk edenlerini 128 nci madde şöyle ifade ediyor : "mürur zaman alacağın muaccel olduğu zamandan başlar; alacağın muacceliyeti bir ihbar vukuuna tâbi ise müruru zaman bu haberin verilebileceği günden itibaren cereyan eder".

$2^{\circ}$ ) Mürur zaman müddetlernin hesabı :

130 ncu madde şu hükmü muhtevidir: "Müddetlerin hesabında müruru zamanın başladığı gün nazan itibare alınmaz ve mürur zaman ancak müddetin son günü kullamlmáksızın geçtiği surette vâki olmuş olur.

mî kanundan evvel ve muahhar umumî kanunla nakız edilmiş olmasın. Maamafih umumî kanun kendisinden evvelki hususî kanunlardaki mürur zamana mütedair ahkâmın mahfuz olacağını beyan etmiş ise, hususî kanunların umumî kanundan evvel oluşuna rağmen yine kabili tatbik olur. 
Bununla beraber borçlann ifası meselesinde müdddetlern hesabına müteallk kadele rburada da tatbk olunuur".

Madde vazıh olmakla beraber izahı zait değildir: Borcun muacceliyet günü mürur zamanın hesabında nazara alınmaz. Maddenin "müddetlerin hesabında mürur zamanın başlaidığı gün (nazan itibare alınmaz) ibaresinden anlaşlacak olan budur.

Mürur zaman müddetinin son günü mürur zamanın tekemmülï günüdür. Ĕger bu günde gerek alacakh, gerek borçlu tarafindan mürur zamanın kat'ı veya tatili esbabiyle alâkalı bir muameleye tevessül edilmemiş ise, ve meselâ alacaklı alacağı mahkeme veya îcrada talep eylememiş ise, mürur zaman tekemmül ederek, borç tabiî biorç haline inkilâp eder ve artık edásı borçlunun ihtiyanna münhasır kalır. Madidenin "ancak müddetin son günü kullanılmaksızın geçtiği suretde..." ibaresinden yukarda izah edilen cihetler anlaşılmak lâzımdır". "Kullanmadan maksat yalnız alacaklı tarafından alacağın borçludan talep edilmesi değildir.

Son gün içinde alacaklı veya borçlu bakımından mürur zamanı kat eden veya tatile uğratan bir keyfiyet vukuu dahi son günün kullanılması manasında tefsir olunmak lâzımdır. Meselấ, A, B den 1000 lira alacaklıdır, alacak 12/VI/1955 gününün hululü ile mürur zamana uğrasa, $A$ bu gün $B$ ye karşı dava ikame eylese, ${ }^{69}$ veya borçlu $B$ o gün A ya olan senetsiz borcunu senede rabt etse veya alacaklı o gün $B$ nin hizmetine girse ${ }^{70}$ son gün kullanılmış olur.

Mürur zaman müddetlerinin hesabı, müddetlerin tatile rastlaması ilh gibi hallende 76 ncı ve müteakip maddelerdeki kaideler nazara alınır.

77 nci maddeye nazaran "bir pazar veya kanunen tattil olarak kabul edilen diğer bir güne tesadüf eden vade kendiliğinden bu günü takịp edip tatil olmayan ilk güne geçer. Hilâfına mukavele muteberdir".

Bu maddenin mürur zaman müddeti için de kabili tatbik olacağnî 130 ncu maddenin 3 ncü bendi sarahati icabnndan ise de, 77 nci maddenin son ibaresi' olan "hilhâfina mukavele muteberdir" hükmü kabili tatbik olamaz. Zira aksi halde mürur zamanın kısaltılı ,uzaltılamayaca-

69) Davanın usulünce ikame edilmiş olması kâfidir; Ilk celsenin bașlayıp başlamaması haizi ehemmiyet değildir.

70) Mürur zaman tatili sebeblerine bakınız. 
ğ kaidesi muhtemel olurdu. Binaenaleyh 77 nci maddenin bu hükmü 127 nci maddedeki mürur zaman müddetlerine tatbik olunamaz ${ }^{71}$.

79 ncu madde hükmünün dahi üçüncü babtaki mürur zaman müddeti için kabili tatbik olamayacağ kanaatini izhara mahal vardır.

6) Mürur zamanm kat'ı ve tatili :

$1^{\circ}$ ) Mürur zamanın kat'1. Md: 133.

Bazı sebepler mürur zaman müddeti son bulmadan evvel hasıl olursa işlemiş olan mürur zaman müddeti nazara alınmaz; mürur zaman bu sebeblerin ortadan kalkması anından itibaren yeniden başlar. Meselâ 10 senelik mürur zamana tâbi bir alacak 9 sene 11 ay hiç talep edilmemiş olsa $10 \mathrm{ncu}$ senenin son ayında borçlu alacakllya rehin verse veya kefil gösterse, işleyen 9 sene 11 ay nazara alınmaz, 10 senelik müddet rehnin verilmesinden veya kefalet senedinin tanzimi tarihinden itibaren yeniden işler.

Mürur zaman borçlunun veya allacaklının fiili ile kat edilir. 133 ncü madidenin 1 nci bendi borçlunun fiili ile 2 nci bendi alacaklının fiili ile olan katı sebeblerini sayıyor.

$2^{\circ}$ ) Borçlunun fiili ile katı :

İhtilâflı bir borcun borçlu tarafından kabulü o borç hakkında mürur zamanın yeni baștan cereyanını icap eder. Ancak ikrarın borcun kabulü maksadiyle vukuu lâzımdır. Borcun bir miktarının ödenmesi hakkı davanın mahfuziyeti şartiyle vâki olmuş ise, kısmî tediye mürur zamanı kesmez ${ }^{72}$. İkrar yalnız asl borcun bir kısmını tediye șeklinde teceili etmez. Faizlerin tediyesi dahi asıl borcun ikran hükmündedir. Ancak işlemiş faizin ödenmesi işlemiş faizin tekabül ettiği resülmal borcunu ikrar sayllir.

Borcun mahkeme dişinda ikran nazara alınmaz ${ }^{73}$. Akraba veya dost'lar veya yabancı eşhas nezdindeki ikrảr mürur zamanı kat etmez.

71) Yani 125 den 140 ncı maddeye kadarki mürur zaman müddetlerinin son günü tatile tesadüf ederse mürur zaman, tatil gününü takip eden ilk günün kullanılmaksızın geçmesi ile behemehal tekemmül eder. Bunun hilâfı șarı edilemez.

72) Temyiz M. 4. H. Dairesi, 14/II/1941 gün ve 249/308 sayılı kararı.

73) T.M. 4. H. Dairesinin 25/11/1946 gün ve 4541/4685 sayll kararına bakınız : Kâmil Tepeci: Notlu ve izahlı Borçlar Kanunu, 1954, sa: 340. 
İkrar, veya tediye mürur zaman vâki olduktan sonra vukubulursa mürur zamanın kat'ı mevzuu bahis olmaz. Mürur zamana uğramış bir borcun ikrarı yeni bir borç tekabüllü hükmündedir ve böyle bir borcun tediyesi tâbiî borcun edası ahkâmına tâbidir: borçlu bilerek ödemiş ise ödediğini istirdat edemez. Alacaklı mürur zamana uğramış olan alacağından bir miktarnnı borçlu tarafindan bilerek ödenmiş olduğunu beyan ile sabık borçlusunun mürur zamana uğramış olan alacağın tamamını ödemeğe icbar edemez. Borçlu 1000 liradan 700 lira ödemiş ise, alacak'l 300 lira hakkında dava ikame edemez. Bu, kısmî tediyenin ancak mürur zaman vâki olmadan evvel borcu ikrar hükmünde olabileceği ve binnetìce mürur zamanın kat'ını intaç eyleyebileceğinin neticesidir. Tekemmül etmis olan mürur zamandan sonra vâki eda halin. de mürur zamanın kat'ı mevzuu bahis olamayacağından alacaklı bütün borç hakkında yeni mürur zamandan bahs edemez, binnetice mütebaki talebe haklı olmaz. Rehin tesis eder veya kefil gösterir ise mürur zaman bu tarihten it tbaren yeni baştan işler. Maamafih esasen rehin veya kefil ile temin edilmiş bir alacağın mükerrer rehin veya kefaletle takviyesi mürur zamanı kat etmez. 133 ncü maddenin 1 nci fikrası hükmü henüz aynî veya şahsî teminat ile garantilenmemiş alacaklara kabili tatbiktir.

\section{$3^{\circ}$ ) Alacaklının fiili ile mürur zamanın kat'ı :}

133 ncü maddenin 2 nci bendi mucibince alacaklı dava veya def'i dava zımninda mahkemeye, hakem veya icraya müracaat veya icraî takibat veya iflâsa müdahale ile alacağın tahsili ile alâkalı usul muamelesine tevessül edirıce mürur zaman kat edilir.

Tatbikatta ehemmiyeti haiz noktalar şunlardır : Yetkisiz mahkemeye müracaat mürur zamanı kesmez $^{74}$.

Alacă̆ın kanunda muayyen makam ve mercilerden gayn makam ve mercilere müracaatle talebi dahi mürư zamanı kesmez. Meselâ devletdeki alacak için vekâ'ete müracaat nazara alınmaz. Alacaklı Devletten olan alecağı için makamatı resmiyeye müracaatde bulunduğunu iddia ile 133 ncü maddeden istifaide edemez ${ }^{75}$.

74) T.M. 4. H. Dairesinin $15 / 10 / 1945$ gün ve $3900 / 3615$ sayll kararma bakınız.

75) Aynı mealde : T.M. 4. H. Dairesinin 1947 gün ve 791/1128 sayliı kararı. 
Adlì müzaheret talebi dava mahiyetinde olmadığından bu sebeble mahkemeye başvurulmuş olmak dahi mürur zaman kat edici bir muamele değildir ${ }^{76}$.

Yalnız cezaî takibat 133 ncü maddenin tatbiki için kâfi değildir. Aynı zamanda ceza mahkemesinde tazminat da talep etmiş olmak lầzımdır. Aksi halde cezayı da mucip bir haksız fiil fâilini velev şikâyete bağlı mevaddarı olduğu cihetle bizzat mağdurun ceza mahkemesine sevketmesi o haksız fiilden doğan teminat hakkındaki mürur zamanı kesmez ${ }^{77}$.

Hukuk şahsiye ceza davasının ikamesiyle birlikte veya bilâhare ta. lep olunabilir. Sonra talep olunmusssa mürur zaman ceza davasının ika. me edildiği anda değil hukuku şahsiyenin talebi anında kesilir.

Müşterek alacaklılardan birinin alacağını mahkeme veya icrada takibi mürur zamanı ancak takipte bulunan alacakh hakkında keser. Diğer alacaklilar müşterek alacağını bu suretle münferit takibe maruz bulunmuş olduğundan istifade edemezler ${ }^{78}$.

Alacağın tahsili ile alâkalı olmayan kazaî müracaat ve muamelât mürur zamanı kesmez. Binnetice ihtiyatî tedbir ve tesbiti delâil muamelâtı 133 ncü maddenin tatbikini mucip olmaz ${ }^{79}$.

Tatbikatda vâki zuhuller sebebi ile kaydı zarurîdir ki mürur zamanın kat'ı ancak tekemmül etmemiş mürur zaman müddeti için mevzuu bahistir. Hasıl olan tekemmül etmiş bulunan mürur zamanın kat'nı iddia mantıka da mugayirdir ${ }^{80}$.

Mürur zamanın kat'ı şu neticeleri tevlit eder :

76) T.M. 4. H. Dairesinin $17 / \mathrm{XI} / 1944$ gün ve $3387 / 3314$ : Kâmil Tepeci, a. g. e. sa. 338 .

77) T.M. 4. H. Dairesinin $27 / \mathrm{X} / 1939$ gün ve $2761 / 2037$ sayll kararı da böyledir. İkame edilen ceza davasından feragat (takibi şikâyete bağlı suçlarda) de tazminattan feragati icap ettirmez.

78) Temyiz. M.T.D. nin 1944 senesinde verdiği $1858 / 513$ sayılı bir kararı da M. 4. H. Dairesinin 31/11/1943 gün ve 3738/3619 sayılı kararına bakınız: K. Tepeci a. g. e. sa: 342.

79) Temyiz M. İç. İf. Dairesinin 1938 senesindeki $425 / 442$ nolu bir kararı da aynı mealdedir.

80) Temyiz M. 4. H. Dairesinin 10/2/1953 gün ve $816 / 628$ sayıl kararı da aynı manadadır. 
i) Mürur zamanın kat'ı umumidir. Yani katıdan borçlu ve kefil müstefit olur.

ii) Kefil hakkında katı borçluları müstefit kılmaz.

134 ncü madde bu esaslara şöyle işaret ediyor : "Mürur zaman müteselsilen medyun olanlardan veya gayn kabili taksim bir deynin müşterek borçlularından birine karşı katedilmiş olunca diğerlerine karșı da kat'edilmiş olur.

Mürưr zaman asıl borçluya karşı kat edilmiş olunca kefile karşı da kat edilmiş olur.

Mürur zaman kefile karşı katedilmiş olunca asıl borçluya karß̧ı katedilmiş olmaz".

Yukarda kaydedilmiş olup maddenin muhtevasına tekabül eden iki neticeyi kısaca izah faydadan hali değildir.

Kat'ı umumidir. A, B ve C den 1000 lira alacaklı olsa, ve yalnı́ $C$ yi mahkemeye veya icraya verse, dava veya icra tâkibatı mürur zaman müddetinin hululüne kadar devam etse, B kendi hakkında borcun mürur zamana uğradığını iddia edemez. B müteselsil borçlu olsun müssterek borçlu olsun hüküm aynidir. Aynı hüküm, asıl borçlunun tâkibi halinde kefil için de tatbik olunur. Kefil hakkında tâkibat asıl borçlu hakkında mürur zamanı kesmez. Zira, kefil asıl borçlunun akdî mukadderatına tâbi olmayı kabul etmiş, fakat asıl borçlu kefilin borcu ile ilgili taahhüde girişmemiştir.

İkinci müddet kat'ından itibaren cereyana başlar. Kat'ın sebebi hangi muamele ise o muamelenin muteber bir şekilde vuku ve husul tarihi yeni mürur zaman müddetinin tekrar cereyana bașlayacağı andır.

Kat'ıdan sonra işleyecek olan yeni müddet eski mürur zaman daha az olsa bile iki halde daima 10 senedir.

i) Borç bir senedde ikrar edilmiş ise.

ii) Blorç bir hüküm ile sâbit olmuş ise.

2 senelik mürur zamana tâib bir borç mevcut olsa, senede bağlansa, veya mahkemede tahsiline karar verilse, senedin tanzimi tarihinden veya hükmün kaziyei muhkeme haline girmesinden itibaren işleyecek olan 10 senelik mürur zamana tâbidir. Eski müddet 10 
seneden daha fazla ${ }^{81}$ bir mürur zamana tâbi olsa bile hüküm değişmez. Filhakika, 135 nci madde, yeni müddetin daima 10 sene olacağını eski müddetin daha kısa olduğu hale münhasır kılan sarahat ve delâlet muhtevi değildir.

136 ncı madde alacaklının fiili ile kat'ı halinde yeni müddetin başlayacağı anı tesbit eden esaslanı beyan ediyor:

i) Mürur zaman bir dava veya defi ile kesilmiş ise, yeni müdde! iki tarafin muhakemeye müteallik her muamelesinden itibaren cereyana başlar. Taraflar davanın devamı müddetince, yani hüküm kaziyei muhkeme haline gelmeden evel dava ile alâkalı muamelede bulunur iseler müruru zaman kesilir. Ancak dava ile alâkalı iki muamele arasında mürun zaman müddeti geçmemelidir. Meselâ alacaklı 6 aylık mürur zamana tâbi alacağı için dava ikame ettiği, mahkemenin tâyin ettiği celse gelmedi, dava müracaate kaldı. Bu halde hâkimin ilk celsede davayı başka güne havalesi tarihinden itibaren mürur zaman cereyana başlamış addolunur. Binnetice davacı ikinci celseye gelmemiş ve 1 nci celse ile ikinci celse arasında bilfarz 1 aylık müddet mevcut olmuş ise, dava ikinci celseyi takip eden 5 ay içinde yenilemez veya tekrar ikame olunmazsa altı aylık mürur zaman hasıl olmuş olur. Dikkat edilecek cihet, mürur zamanın davanın müracaate kaldığı tarihten itibaren değil ikinci celseye tâliki gününden yeni baştan işlemeye başlayacağıdır.

Yine bilfarz bir senelik mürur zamana tâbi bir alacak davası temyiz edilse, temyiz tarihi ile rüyet tarihi arasında bir seneyi mütecaviz müddet gecse alacak yine mürur zamana uğrar. Bunun içindir ki, kısa müddetli mürur zamana tâbi davalan Temyiz mahkemesi takdimen ve mürur zaman haddini geçirmeksizin rüyet etmeğe mecburdur ve etme:rtedir de. Zira muhakemeye müteallik her muameleden sonra mürur zaman tekrar' ceryana başlar.

Temyiz ilâmının kaleme havale edilmesi ile tebliğ veya tebellüğg tarihi arasında 10 senelik müddett hulûl etmemiş ise, tebliğ veya tebeìlïğ dahi mürur zamanı keser 82

ii) Kati icra tâkibatından ileri gelmị̣ ise mürur zaman tâkiple

81) Meselâ haksız fiillerde hazsıı fiil aynı zamanda cezayı da müstelzim ise ve ceza kanunundaki mürur zaman bilfarz 20 sene olsa, alacaklı artık 20 seneden müstefit olamaz.

82) Temyiz M. 4. H. Dairesinin 1953 yllında 3379/2511 sayılı kararı da böyledir. 
alâkah her muameleden itibaren yeniden cereyana başlar. Meselâ belediyeye borçlu olan bir şahıs hakkında tahsili emval kanununa göre takibat yapulp 1000 liradan 100 lirası tahsil edilse, aradan 10 sene geçse 900 lirayı Belediye bir daha talep edemez. Zira 100 lira icra muamelesiyle elde edilmiş ve bundan sonra mürur zaman tekrar cereyana başlamış$\operatorname{tir}^{83}$.

Dosyanın muameleden kaldınlması ve meselâ davacı gelmediğinden davanın müracaate bırakılması muhakeme ile alâkalı muameleden değildir. Binnetice mürur zaman dosyanın muameleden kaldırılması anından itibaren değil, buna takaddüm eden muhakeme ile alâkalı ilk muameleden itibaren yeniden cereyana başlar ${ }^{84}$.

$\left.4^{\circ}\right)$ Mürur zamanın tatili : Md. 132.

Mürur zamanın tatilinde işlemiş olan müddet bakidir. Tatil sebebi kalkınca mürur zaman bu sebeb dolayısiyle durduğu yerden cereyana devam eder. Katıda olduğu gibi, tatilde işleyen müddet zayi olmaz.

132 nci madde mürur zamanı tatil eden esbabı saymaktadır. $\mathrm{Bu}$. sebebleri kısaca izah lâzımdır :

aa) Velâyet :

Çocuk ana babasının velâyeti altında bulunduğu müddetçe bunlar zimmetindeki alacağı hakkında mürur zaman cereyan etmez. Borç velâyet mevcut iken doğmuş ve muaccel olmuş ise hal böyledir. Bazan velâyet bilâhare teessüs edebilir; bu halde isslemekte olan mürur zaman tatile uğrar. Meselâ çocuk üzerinden babanın velâyet hakkı nez edildiği sırada çocuk babasından alacaklı olur, bilâhare baba velâveti iade olunursa, işlemekte olan mürur zaman velâyet hakkı dolayısiyle durur. Çocuk rüște vâsıl olduğu veya velâyet nez edildiği andan itibaren mürur zaman cereyana devam eder.

Kanun 132 nci maddenin 1 nci fikrasında meșru çocuğun alacağını nazara alm.ştır. Zira bu fikra çocuğun ana babasından olan alıcağını velâyetin mevcudiyeti anında mevicut farz etmekte ve ona göre hüküm sevketmektedir. Diğer cihetten "Çocukann baba ve analanna

83) Temyiz M. 4. ncü H. Dairesinin $18 / 3 / 1944$ gün ve $574 / 862$ sayılı kararı da bu mealdedir.

84) Temyiz M. 4. Dairesinin aynı kararı bu ciheti icra dosyasmın muameleden kaldırılması dolayısiyle tezekkür etmiștir. 
karșı olan alacakları hakkında" demekle evlilik anında velâyetin müştereken istimali kaidesini nazara alarak hüküm sevk etmiştir.

Evlilik dışı çocuklar kaidèten analarının velâyeti altındadır. Bunlaın babalanna nesebi müesses değilse babalannın bu çocuklar üzerinde velâyeti ve binnetice çocuğun fiilì babasından olan alacağı hakkında mürur zamanın tatili mevzuu bahis olmaz. Maamafih kendisine karșı nesebi teessüs etmiş olan bir babanın çocuk lüzerinde mutlaka velâyef hakkına sahip olması da icap etmez. Yalnız nafakaya müncer olan babalık davası nesep tesis edemiyeceğinden çocuğun nafaka itasına mahkûm olan babasından olan alacağı da tatile uğramaz.

Yukarda zikredilen esaslarla Medenî kanunun velâyet ile alâkalı sair hükümleri nazara alınarak velâyetin mürur zamanı tatili meselesi halledilmek lâzımdır.

\section{bb) Vesayet :}

Vesayet altında bulunan kimselerin vasi veya sulh ve Asliye hâkimlerinde olan alacakları hakkında mürur zaman ya bidayeten cereyan etmez veya cereyana başlamıs olanı tatile uğrar. Vesayet altında bulunan kimse küçük olsun reşit olsun aynı kaide tatbik olunur.

cc) Evlilik :

Evliliğin devamı sırasında kan kocanın yekdiğerindeki alacaklan hakkında mürur zaman işlemez. Alacak nikâhtan evel doğmuş ve muaccel hale gelip mürur zaman cereyana bașlamış ise nikâh ile tatile uğ. rar. Ve evliliğin zevaline kadar işlemez. Íki nişanlıdan biri nișanlılık es. nasında diğerinden 10 senelik mürur zamana tâbi 100 lira alsa evlenmeye kadar 5 sene geçse, evlenseler, 10 sene sonra boșansalar, 4 sene 10 ay sonra tekrar evlenseler, sonra boşansalar, alacaklı olan tarafin 1000 lirayı evliliğin zevalinden sonra iki ay içinde talep etmesi icap eder.

Mahkeme nikâh rabıtasının zevalini tahkik etmelidir ${ }^{85}$. Evlenme bâtıl olsa dahi fesih ile zevale kadar sahih evlenmenin hükmünü tevlit edeceğinden mutlak butlanla bâtıl evlenme dahi mürư zamanı tatil edeı. Ayrllk halinde mürur zaman yine işlemez. Boşanma, ölüm, fesih butlan karan ile mürur zaman cereyana devam eder ${ }^{86}$.

85) Temyiz M. 4. ncü Dairesinin 1944 gün ve 2438/1861 sayılı karan da böyledir. Trararı.

86) Temyiz M. 4. H. Dairesinin 15/VII/1936 gün ve 2914/1589 sayılı 
dd) Hizmet akdi :

Hizmet akdinin devaminca müstahdemlerin istihdam edenlerde olan alacaklan hakkında mürur zaman dahi cereyan etmez. Kanun "hizmetçilerin" demekte ise de bundan murat müstahdemdir.

Hizmet akdi tarafeynin nzası, fesih veya tarafeyinden birinin ölülü ile son bulmakla mürur zaman da cereyana devam eder.

A nın B de 1000 lira alacağı olsa, mürur zaman 5 senelik olsa, 4 sene işledikten sonra $A, B$ nin müstahdemi durumuna girse ve 10 sene emrinde çalıştıktan sonra istihdam eden ölse, A bir sene içinde 1000 lirayı mirasçılardan talep etmekle mükelleftir.

132 nci maddenin 4 ncü fikrasında mezkûr alacak tâbiri şâmildir: yani yalnız hizmet ücretlerine münhasır değildir ${ }^{87}$.

(Devam edecek)

87) 132 nci maddenin 3 ncü bendinde mezkûr alacak para alacağına değil her nevi alacağı şâmildir : T.M. H.U.H. 7/V/1947 gün ve 135/19. 